\title{
FETC/EPRI BIOMASS COFIRING COOPERATIVE AGREEMENT
}

\author{
Quarterly Technical Report \\ Reporting Period:01/01/98 to 03/31/98 \\ Author: E. Hughes and D. Tillman \\ Report Issue Date: August, 1998 \\ DE-FC22-96PC96252-08
}

Electric Power Research Institute (EPRI)

3412 Hillview Avenue

P.O. Box 10412

Palo Alto, CA 94304-1344 
"This report was prepared as an account of work sponsored by an agency of the United States Government. Neither the United States Government no any agency thereof, nor any of their employees, makes any warranty, express of implied, or assumes any legal liability of responsibility for the accuracy, completeness, or usefulness of any information, apparatus, product, or process disclosed, or represents that its use would not infringe privately owned rights. Reference herein to any specific commercial product, process, or service by trade name, trademark, manufacturer, or otherwise does not necessarily constitute or imply its endorsement, recommendation, or favoring by the United States Government or any agency thereof. The views and opinions of authors expressed herein do not necessarily state or reflect those of the United States Government or any agency thereof." 


\section{ABSTRACT}

This quarter much progress was made in promoting cofiring through the many FETC/EPRI backed projects. During January 1, 1998 to March 31st, 1998 significant contractual agreements were arranged for future testing and analyses of previous testing were conducted. Most notable was the analysis done on the testing run at the Tennessee Valley Authority's Colbert Fossil Plant that showed no significant impacts to the plant boiler due to cofiring. Northern Indiana Public Service Company also identified Bailly \#7 as the site of the next series of tests using their plants. Other work done on these projects primarily focused on continued cofiring development.

This report summarizes the activities during the first quarter in 1998 of the FETC/EPRI Biomass Cofiring Cooperative Agreement. It focuses upon reporting the results of testing in order to highlight the progress at utilities. 


\section{TABLE OF CONTENTS}

ABSTRACT

$0-1$

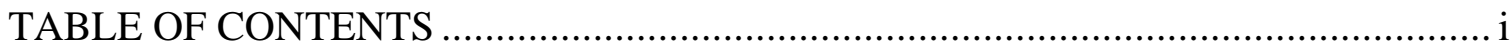

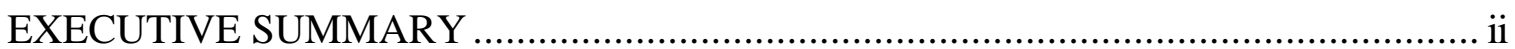

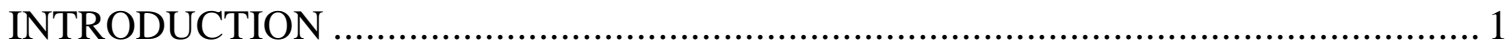

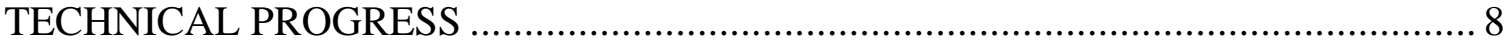

Project $1-$ Combustion Testing at the Seward Generating Station ........................... 8

Project 2 - Fuel Preparation Tests at Greenidge Generating Station .......................... 8

Project 3 - Precommercial Testing at TVA Fossil Plants ....................................... 8

Project 4 - Switchgrass Testing at Blount St. Station of Madison Gas \& Electric....... 14

Project 5 - High Percentage Cofiring with Southern Company................................. 14

Project 6 - Cofiring Testing at Michigan City Generating Station of NIPSCO........... 14

Project 7 - Testing Cofiring of Switchgrass by Nebraska Public Power District/Sandia16

Project 8 - Waste Plastics Cofiring at Duke Power ........................................... 16

Project 9 - Plastics/Fiber/Pulp Waste Cofiring with SCE\&G.................................. 17

Project 10 - Urban Wood Waste Cofiring in Pittsburgh, PA................................... 17

Project 11 - Toxic Emissions from Cofiring Evaluation ....................................... 17

Project 12 - Fuel/Powerplant Model Development ........................................... 17

Project $13-\mathrm{CO}_{2}$ Utilization in Algal Systems .................................................... 17

Project 14 - Combustion Tests and Combustor Development ................................. 17

Project 15 - Support for Ash Sales from Cofiring Plants ....................................... 17

Project $16-\mathrm{CO}_{2}$ Capture and Disposal Options .................................................. 17

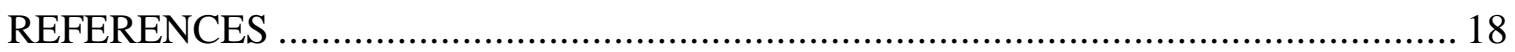

Cofiring Wood Waste With Coal at the Seward Generating Station ................... 19

Cofiring Urban Wood Waste With Powder River Basin Coal at the

Michigan City Generating Station.............................................................. 35 


\section{EXECUTIVE SUMMARY}

The Sixth Quarter of the FETC-EPRI contract, Jan 1, 1998 through Mar 31, 1998, was characterized by major contractual activities as well as continuing progress on the technical fronts. On the contracting front, the following activities occurred:

- $\quad$ The major contract between EPRI and Foster Wheeler Environmental Corporation (FWENC) was novated to Foster Wheeler Development Corporation (FWDC); as of January 1, 1998, FWDC assumed responsibility for implementing the cofiring program for EPRI

- $\quad$ The host site agreement negotiations between GPU Genco and EPRI were initiated in order to facilitate the 3-year cofiring demonstration at the Seward Generating Station of GPU

Technical work that proceeded during the sixth quarter of the contract included the following:

- $\quad$ Continuing commercial operations of the Greenidge Station cofiring facility of New York State Electric and Gas (NYSEG)

- Commercialization of the cofiring program at the Colbert Fossil Plant of the Tennessee Valley Authority (TVA)

- $\quad$ Selection of the Bailly Station boiler \#7 as the follow-up demonstration site for biomass cofiring at NIPSCO, and performing initial calculations concerning blending wood waste with petroleum coke at that site in order to achieve a cost-effective and environmentally beneficial program

- $\quad$ Transmittal of the combustion spreadsheet providing heat and material balances for fluidized bed boilers

- Continued development of a cyclone combustion spreadsheet for field applications 


\section{INTRODUCTION}

Cofiring has been developed to accomplish the following economic and environmental objectives:

1. Mitigate fossil $\mathrm{CO}_{2}$ emissions from coal-fired boilers

2. Reduce $\mathrm{NO}_{\mathrm{x}}$ and $\mathrm{SO}_{2}$ emissions from cyclone and $\mathrm{PC}$ boilers

3. Provide a mechanism for generating cost-effective green power

4. Provide customer service to utility clients, maintaining loads

5. Increase fuel diversity for utilities

The practice of cofiring is generally considered to be the least cost method for getting utilities into the biomass arena; and biomass is considered to be the most cost-effective solar energy system for cloudy climates. Further, biomass is dispatchable renewable power or "green power."

For the period of 1994 through 1997, utilities encouraged EPRI to pursue full-scale testing and demonstration of cofiring to reduce the uncertainties associated with this practice. Tests have been conducted by TVA, GPU Genco, NIPSCO, Southern Company, NYSEG, and numerous other utilities.. In total, over 20 cofiring parametric tests have now been conducted. At this juncture, the cofiring program can convert from parametric/performance testing to longer term demonstrations. The 16 FETC/EPRI projects are at the forefront of the cofiring effort in terms of scope, percentage cofiring, boiler size, and the ability to quantify the results of cofiring. These projects provide a bridge from the current economic conditions to a future when

The 16 projects in the FETC/EPRI program contribute significantly to that bridge. They are summarized below.

\section{Combustion Tests at GPU's Seward Plant (30 MWe, PC)}

EPRI and GPU (an EPRI member utility operating the Seward power plant near the Johnstown, Pennsylvania headquarters of GPU's Penelec system) will arrange for other cofunding to augment PETC's cofunding and will conduct a test of mid-level cofiring in a wall-fired PC unit using separate feed for the wood (i.e., not fed through the pulverizers along with the coal, 
as was done in the recent test cosponsored by PETC, EPRI, GPU and the State of Pennsylvania at Penelec's Shawville plant in November 1995).

2. Fuel Preparation Tests at NYSEG's Greenidge Plant (100 MWe, PC)

EPRI is cosponsoring New York State Electric and Gas Company (NYSEG) in a test program that focuses on the preparation of wood fuel for cofiring in a tangentially fired PC unit with separate feed for the prepared wood fuel. Size reduction equipment, such as wood "grinders" or hammermills, and drying equipment will be evaluated, and the suitability of the prepared product tested in full-scale com-bustion in the $100 \mathrm{MWe}$ boiler at NYSEG's Greenidge plant. Mid-level, i.e., about $10 \%$ by heat, cofiring is planned.

3. Pre-commercial Test Runs at TVA ( 200 MWe)

EPRI is cosponsoring the next testing program at TVA, this one being the long-term "pre-commercial" test runs to cofire wood at levels up to $10 \%$ by heat, starting at the cyclone plant (Allen) in Memphis, and continuing at one of TVA's pulverized coal plants.

4. $\quad$ Switchgrass Cofiring with Madison Gas \& Electric (50 MWe)

EPRI is cofunding the University of Wisconsin at Madison in a test program being conducted by the University and the local utility (Madison Gas and Electric) at MG\&E's Blount Street Station, where an existing retrofit to burn refuse-derived fuel (formerly) and shedded paper waste (currently) in a wall-fired PC unit is to be used to conduct the first U.S. test of cofiring switchgrass along with coal in a full-size utility boiler.

\section{High-level Cofiring with Southern Company (50 MWe)}

Southern Company Services has discussed with EPRI a potential cosponsored project to do long-term testing of high-level (i.e., up to $40 \%$ by heat) cofiring of wood with coal, perhaps with some natural gas overfire, in a tangentially-fired PC boiler in Savannah, Georgia. This project would be a follow-up to an initial set of short test runs there in 1993, which indicated that separate feed of this much wood was possible. 
This test will provide the opportunity to explore the upper limits of cofiring wood with coal in an existing PC boiler.

\section{Study and Testing with NIPSCO ( 500 MWe, Cyclone)}

EPRI is completing a study, cofunded by EPRI and Northern Indiana Public Service Company (NIPSCO), to evaluate the fuel supply and the power plant operations for cofiring wood in a full-size cyclone boiler as one of NIPSCO's voluntary measures to reduce emissions of fossil $\mathrm{CO}_{2}$ under the Climate Challenge program of the federal government. The next phase, assuming the expected favorable findings that cofiring is a low-cost $\mathrm{CO}_{2}$ mitigation measure, is to be a cofunded test at, perhaps, NIPSCO's Michigan City plant, where manufacturing process waste wood is the expected source of relatively dry wood already at small size and with potential for a $5 \%$ by heat cofiring operation in an urban area outside of the normal wood products regions of the South, Upper Midwest or Pacific Northwest.

\section{Switchgrass Test with Nebraska Public Power District}

One of EPRI's members, the Nebraska Public Power District (NPPD), has expressed interest in a preliminary evaluation of switchgrass cofiring, an evaluation that can be performed without commitment to a full-size unit test. EPRI has suggested to NPPD an evaluation based on laboratory testing at the Sandia National Laboratory's Combustion Research Facility in Livermore, California. With PETC cofunding this would test the ability of the well-controlled, well-monitored test facility at Sandia to provide data and analysis capable of predicting the potential for the fouling of superheater tubes by the cofiring of high-alkali biomass, namely switchgrass, with coal. Combined with (1) the Madison test (Item 4, above), in which NPPD will participate, and (2) the series of tests done by Sandia on both biomass fuels and coals for DOE, NREL, PETC, EPRI and industry during the past three years, and (3) PETC's in-house testing of switchgrass/coal cofiring at CERF, this new project is expected to reveal the potential and the limits of laboratory testing as a facilitator of decisions on biomass cofiring. 
8. Waste Plastics Cofiring with Duke (50-200 MWe, PC)

EPRI, Duke Power Company (Duke), and the National Plastics Council have cosponsored a laboratory test and engineering analysis of the cofiring of clean plastic manufacturing wastes with coal in a PC boiler. The next step is a unit test at full-size in a PC boiler, perhaps at 50 MWe or perhaps up in the 200 MWe range, approximate size. While actual biomass cofiring, i.e., waste wood cofiring, may or may not be part of the first unit tests, this project is important for the future of biomass cofiring because it involves a major investor-owned, coal-firing utility, located in a region of a major wood-products industry as well as major, and changing, agricultural and meat/poultry industries, as well as textile industries. It is an excellent test of waste cofiring justified on purely business grounds (fuel savings and customer service) but with potential to move toward environmental grounds, if warranted.

9. $\quad$ Plastic/Fiber/Pulp Wastes with SCE\&G ( $100 \mathrm{MWe}, \mathrm{PC})$

EPRI has discussed possible follow-on testing with South Carolina Electric and Gas Company (SCE\&G), tests that would be a follow-on to a test run in 1993 where mixed plastic and wood fiber were fired with coal to determine technical feasibility for disposal of an industrial customer's manufacturing residues. Other residues, consisting primarily, or entirely, of pulp wastes rather than plastic may be tested next. Or, a second test, longer and with more variations, using the same plastic/ fiber residue may be the prime focus. The rationale for this as a biomass cofiring test is similar to that for Duke (a neighboring utility in the same wood industry region), but the scope is more directly on biomass, as well as plastic, as fuel, and the options for boiler retrofit may be different.

\section{Urban Wood-Waste Study and Test in Pittsburgh}

PETC has suggested that EPRI join an evaluation of the urban wood waste resource in the industrial/commercial/residential region of Pittsburgh and environs. Course, low-cost or no-cost wood wastes would be fired with coal in a stoker boiler at the Bellefield Boiler Plant owned by a consortium that includes the University of Pittsburgh. The University would oversee and monitor a long-term test of low-level (about $2 \%$ by heat) cofiring of 
urban wood wastes (including tree trimmings) together with coal. The key elements of the test would be off-site wood processing, assessment of the urban wood supply and cost by means of actual fuel procurement, and, perhaps, assessment of fines separation and separate cofiring of fines in a normal utility boiler (i.e., PC or cyclone).

\section{Toxic Emissions}

Both EPRI and PETC have measured trace emissions and effluents from the combustion of coal and from ash resulting from coal combustion. In this new project, EPRI and PETC will combine their respective data sources, test facilities and expertise in an effort to determine the extent of trace emissions or effluents from the cofiring of wood or other biomass wastes with coal. After an evaluation of data on fuels and control processes, including data on fuel chemistry, ash chemistry, emissions, emission control systems, liquid waste streams and solid waste streams, EPRI and PETC will plan and conduct a test to measure and/or predict the emissions, if any, of toxic species that may arise from cofiring bio-mass with coal. This project will explicitly consider a test at the ECTC (Environmental Control Test Center) at the Kintigh power station operated by NYSEG near Buffalo, New York. The best site and fuel combination for a test will be identified and a test will be conducted, if the evaluation indicates that a useful measurement of toxic emissions can be obtained.

\section{Fuel/Powerplant Models, Analysis and Interpretation}

In order to interpret results from this entire set of projects and to facilitate the transfer of the results to the industry, EPRI will develop a SOAPP ("State-of-the-Art Power Plant") module for evaluating wood cofiring situations. SOAPP already has modules for combustion turbine power systems, and SOAPP modules for conventional utility PC and cyclone plants, and also FBC and coal gasification systems, are under development. By July 1996, the first SOAPP cofiring module will be completed, for natural gas as the cofired fuel in a reburn or other mode. This new project (No. 12 of the PETC/EPRI cofiring program) will add wood cofiring to SOAPP, and also will add a fuels database capable of putting the properties of each new cofiring fuel into a context for comparison to some 50 other fuels and for prediction of slagging/ fouling/agglomeration potential in 
comparison to those other fuels. The result will be a model that will make possible the interpretation of test results from all the cofiring experiments in terms of the performance and cost impacts on a state-of-the-art coalfired powerplant. Currently, but separate from this proposal, EPRI and PETC are cooperating on the EPRI-developed CQIM computer model by doing tests to obtain data on slagging/fouling for blends of coals. This work will be used and expanded under this PETC/EPRI biomass cofiring project. EPRI's fuels database for biomass and other alternative fuel properties (including slagging indices, etc.) will be incorporated into CQIM, SOAPP and other analytical frameworks as appropriate. EPRI's biomass resource assess-ments and tools for developing supply/cost curves will be applied as appropriate to address regional or local biomass resource issues important to PETC.

13. $\mathrm{CO}_{2}$ Utilization in Algal Systems for Wastewater Treatment

EPRI and PETC have independently done experiments and studies of systems that can take advantage of the high rates of capture of $\mathrm{CO}_{2}$ by aquatic biological systems such as seaweed (kelp), microalgae (ocean and land-based) and halophyte species (both in water and on dry land). This new project under this PETC/EPRI cofiring project will assess what appears to be one of the few near-term options for an algae-based system to contribute to reductions of $\mathrm{CO}_{2}$ emissions: the use of $\mathrm{CO}_{2}$ to speed the growth of algae in water treatment facilities. This approach adds a coproduct value, namely the improved performance of the water (i.e., sewage) treatment plant, that may make the system one of the low cost options for near-term $\mathrm{CO}_{2}$ mitigation. Two forms of fossil $\mathrm{CO}_{2}$ reduction are involved: (1) capture of $\mathrm{CO}_{2}$ into a biomass form, i.e., a process similar to carbon sequestration in forest biomass, but in this case coupled directly to use of a $\mathrm{CO}_{2}$-enhanced stream like powerplant fluegas; and (2) replacement of a fossil fuel by a biomass fuel, as the algae grown with the enhanced $\mathrm{CO}_{2}$ stream replace fossil fuel, i.e., a process similar to the $\mathrm{CO}_{2}$ recycling inherent in all uses of biomass fuels replacing fossil fuels.

\section{Combustion Tests and Combustor Development}

EPRI and TVA have sponsored an initial assessment of slagging combustion as a way to use high-alkali biomass as fuel in power generation 
without having to solve the problems associated with gas cleanup to meet the purity required by the gas turbines in biomass gasification combined cycle power systems. PETC has completed the first in a planned series of bench-scale tests of the cofiring of high-alkali fuels with coal in CERF (Combustion Environment Research Facility) at PETC. This new project in the PETC/EPRI cofiring program will use test systems at PETC to obtain data to predict performance and guide design for use of high-alkali biomass fuels in mid- to high-level fractions (approximately $20 \%$ to even $100 \%$ of the heat into a coal-fired power system). The new project will start with follow-up design and fuel/ash studies that apply and interpret relevant work already completed. Tests will be planned and performed as appropriate, in accord with assessments and plans prepared by EPRI and PETC staff and contractors, and in accord with an implementation plan approved by PETC.

\section{Ash Sales}

An immediate barrier to the cofiring of biomass with coal in existing coalfired powerplants is the potential that the flyash from the cofired operation of the plant will not be purchased by the cement industry, which is now the best market for flyash from coal-fired utility boilers. This project will develop and communicate an action plan that will enable a cement industry standards board to make as early as possible a finding that cofired ash is acceptable for purchase from utility powerplants.

\section{6. $\mathrm{CO}_{2}$ Capture and Disposal}

This project will conduct a series of feasibility studies of various pro-posed options for capture and disposal of carbon dioxide from U.S. coal-fired power plants. Consideration will be given to both land and ocean-based disposal options in an effort to determine which options would be most amenable to fossil carbon sequestration for both existing and future U.S. power generation capacity. This effort will build on the results of studies previously performed by the International Energy Agency (IEA) Greenhouse Gas Research and Development Program with joint DOE and EPRI funding. 


\section{TECHNICAL PROGRESS}

\section{Project 1 - Combustion Testing at the Seward Generating Station}

The combustion testing demonstration program at the Seward Generating Station experienced significant progress during the sixth quarter. Contracting was initiated between Foster Wheeler Development Corporation and EPRI to implement the cofiring concept. Negotiations for a host site agreement between GPU Genco and EPRI were initiated during this quarter. Meetings were held at the plant to discuss early concepts of the cofiring system.

One concept emerged during this quarter: using pentachlorophenol-treated poles and creosote-treated poles as part of the fuel supply. Currently these poles may be given away; for the most part they are landfilled at $\$ 80 /$ ton to $\$ 200 /$ ton. Assessments of the quantities of such poles were initiated. Development of a combustion testing program was also initiated during this quarter.

\section{Project 2 - Fuel Preparation Tests at Greenidge Generating Station}

The cofiring program at Greenidge Generating Station proceeded as commercial activity during this quarter.

\section{Project 3 - Precommercial Testing at TVA Fossil Plants}

The Colbert Fossil Plant of TVA, in Tuscumbia, AL, commercialized cofiring at a low $(<5$ percent by mass) level. The initial wood handling system designed for the plant under the cofiring cooperative agreement is described below. Following consideration of the fuel handling system, this report summarizes the test program and the results of that testing.

\section{The Colbert Coal Yard}

The Colbert coal yard is stocked with coal supplied from single conveyors that deliver coal from each of two barge unloaders. There is no coal crusher and all sizing is done on the coal belt that moves coal Southward from the barge unloader to either the stockpile or directly to the belt lines supplying the coalbunkers. Two stockpiles of coal are maintained. One is a low sulfur coal stockpile for the four small units $\left(192 \mathrm{MW}_{\mathrm{e}}\right.$ each). The other is a 
high sulfur coal stockpile for Unit $5\left(550 \mathrm{MW}_{\mathrm{e}}\right)$. A reclaim hopper is also provided for each stockpile.

Each of the reclaim hoppers consist of two adjacent hoppers covered by a grizzly or steel grate with a vibrating feeder located under each hopper. Each of the two feeders for the reclaim hopper feeds a common reclaim conveyor belt. This conveyor belt then feeds either one of two parallel coal belt lines on the North side of the coal yard.

Each of the coal belt lines is a series of five belts that are used to fill the coal bunkers. The first conveyor belt runs Westward, parallel to and the entire length of the coal yard. A transition point places it on an underground belt that moves the coal under the roadway. Another underground transition moves the coal at a right angle to the South to a third belt. This belt moves the coal above ground and to another right angle transition point. Here the coal is placed on the fourth belt where it moves again Westward to the plant bunker room. The coal moves onto a fifth belt in the tripper room from which it is placed into the coal bunkers.

Each of the two coal belt lines is designed to provide 700 tons of coal per hour. They may be used one at a time or together. Coal feed rate is measured by a belt scale that is installed on each coal belt line prior to entry into the plant.

The coal yard is drained into a containment drainage ditch so that all runoff can be properly monitored and treated.

\section{Location of Wood Fuel Storage, Processing, and Handling}

The location chosen for wood fuel storage, processing, and handling was on the Northeast corner of the coal yard adjacent to the high sulfur coal stockpile and reclaim hopper. This provided the advantage of drainage containment of tannic acid runoff from the wood. It was also next to a roadway that allowed easy routing of delivery trucks from the truck scales. Introduction of the wood fuel was through the reclaim hopper where, it could be easily conveyed to either coal belt line.

\section{Wood Fuel Deliveries}

Sawdust was delivered to the Colbert Plant via trucks. They were tractor-trailer trucks with walking floor van trailers. Each was 40-45 feet long and was capable of delivering up 
to 28 tons of sawdust since Alabama has a gross weight limit of 88,000 pounds for this type of truck.

The trucks were weighed on truck scales located at the plant. They were then unloaded in the coal yard. Unloading was accomplished in about ten minutes.

\section{Wood Fuel Storage}

One purpose of this commercialization program was to determine problems associated with seasonal changes in weather conditions. A decision was made to provide a semipermanent storage facility for the wood fuel.

A 40' x 200' shed was constructed next to the reclaim hopper and with the longest dimension running East to West. In this area, this type of structure is commonly referred to as a hay barn or pole building. The supports were $6 "$ × $6 "$ treated pine posts and steel trusses were used to form the roof. It was covered on three sides and the top with galvanized siding. The posts were on 10' centers on the closed sides of the building. On the South or open side, the posts were on 20' foot centers. This allowed for easy access by the front-end loader and trucks.

The height of the building was designed to permit operation of a front-end loader inside of the building and to allow trucks to back into the building. Concrete barriers like those used on road construction projects, called jersey or rail barriers, were used along the sides of the building. This provided some protection to the building sides and provided a backing surface for the front-end loader when it was picking up sawdust. Lights were provided to support operations during the non-daylight or cloudy conditions.

Because the only available roof truss design was an A-pitch rather than a slope pitch roof, gutters and downspouts were installed on the North and South side of the building. All drainage from the downspouts was routed to the coal yard drainage ditch.

\section{Measurement and Metering of Wood Fuel Feed Rate}

The West Side of the pole building had an opening for a wood fuel conveyor. The wood fuel conveyor angle was adjusted such that wood fuel could be placed into the reclaim 
hopper or the reclaim hopper could still be used for its primary design function of feeding coal to the plant.

Two feeders fed the wood fuel conveyor. Each feeder had a hopper and an independently adjustable metering feeder belt. The wood fuel conveyor and feeders were placed in a tee arrangement, with the feeders parallel to the East Side of the pole building. Each feeder was set to provide a wood fuel feed rate of $4 \%$ for a coal feed rate of 700 tons. This allowed the use of one or two feeders depending on how many coal belt lines were in use. The wood fuel conveyor and the metering feeder hoppers were operated by hydraulic motors driven by a diesel engine powered hydraulic pump.

The conveyor belt between the reclaim hopper and the coal belt line was fitted with a belt scale. The readout device for the belt scale was placed inside the pole building. This provided the heavy equipment operator with the wood fuel feed rate and allowed adjustment of the feed rate as needed.

\section{Initial Material Handling Design}

The initial material handling design placed the delivered fuel on the coal yard. A front-end loader then placed the sawdust in a rented trommel screen fitted with $1 / 4$ " screens. The trommel screen was a trailer mounted portable model and placed parallel to the open side of the pole building. The capacity of the trommel screen was variable with a maximum output of about 20 tons per hour. It was diesel powered and used hydraulic motors to drive the conveyors and trommel screen.

The trommel screen discharged the screened sawdust into the pole building. It was then moved into a larger storage pile within the building by the front-end loader. When sawdust was to be blended with coal, the front-end loader was used to place it into the feeder(s) for metering into the reclaim hopper. This rate was either 29 or 58 tons per hour depending on the number of feeders in service. The oversized material contained bark, slabs, and sticks. It was used as a mulch product and was removed by both the sawdust supplier and plant employees.

The reclaim hopper vibrator feeders were not turned on one occasion during the early operation. This caused the hopper to fill with sawdust. This would have normally caused a bridging issue. Once the vibrator was turned on the material smoothly fed through the 
hopper. They vibrating feeders also vibrated the hoppers and allowed for good sawdust flow in rainy periods.

\section{Final Material Handling Design}

With the success of the initial cofiring, the trommel screen was replaced with a higher capacity unit owned by TVA. This unit was identical in design layout and had a maximum capacity in excess of 60 tons per hour, in place of the smaller unit. Again the acceptable wood fuel screened for transport to the coal pulverizers was $<1 / 4$ " particles

A conveyor was added between the sawdust discharge conveyor of the trommel screen and the South feeder. The trommel screen hydraulic pump powered the conveyor. This allowed direct feeding without the two intermediate handling steps of the prepared fuel. Both the trommel screen and the feeder were adjusted depending upon the number of coal belt lines in service.

The delivery trucks delivered the fuel directly into the pole building. From the pole building, the material was handled only once and placed directly into the trommel screen for processing and feeding into the reclaim hopper. This design allowed for operation during periods of light rain. The wood fuel was only moved outdoors for screening and feeding to the reclaim hopper.

\section{$\underline{\text { Subsequent Design Modifications }}$}

Since commercialization, the Colbert Fossil Plant installed a truck dump to increase the transportation systems available for delivering biofuel, and to reduce the final cost of such transportation. This truck dump was integrated into the overall process with particular attention to minimizing labor required for handling clean wood waste.

\section{Results of the Test Program}

The test program was designed to evaluate the impacts of cofiring on boiler operations and on the formation of emissions. Boiler capacity, efficiency, and emissions formation became the focus of the effort. Resolving these issues formed the basis for commercializing cofiring. 
The test results documented that there was no impact of low percentage cofiring on boiler capacity. Mill amps did increase modestly when cofiring, and mill feeder speeds also increased when cofiring. The plant had sufficient spare pulverizer capacity to handle the biofuel/coal blend without problems. Further, cofiring had no significant impact on sieve analysis of the product fuel, as shown in Table 1. This result may be the result of using ball and race mills. Tests at Kingston Fossil Plant, where bowl mills are employed, indicated some deterioration of sieve analysis with increasing percentages of wood waste firing, even at low percentages.

Table 1. Weighted Average Fineness Test Results from Colbert Fossil Plant

\begin{tabular}{|c|c|c|}
\hline Screen Size & March 6 (no sawdust) & March 7 (4 \% sawdust) \\
\hline Passing 50 mesh & $99.6 \%$ & $99.7 \%$ \\
\hline Passing 100 mesh & $95.2 \%$ & $95.9 \%$ \\
\hline Passing 200 mesh & $67.1 \%$ & $67.8 \%$ \\
\hline
\end{tabular}

Cofiring did not impact boiler efficiencies. Table 2 shows efficiencies measured during some parametric tests. It illustrates the fact that low percentage cofiring does not degrade boiler efficiency relative to coal-only firing.

Table 2. Heat and Material Balance Results of Colbert Tests

\begin{tabular}{|c|c|c|c|c|}
\hline Test Number & Date & Percent Wood & Main steam flow (kpph) & Efficiency (\%) \\
\hline 0 & $2 / 10$ & 0 & 870,9 & 82.6 \\
\hline 1 & $3 / 6$ & 4 & $1,236.2$ & 83.5 \\
\hline 2 & $3 / 6$ & 4 & $1,087.3$ & 82.9 \\
\hline 3 & $3 / 7$ & 4 & 927.8 & 83.5 \\
\hline 4 & $3 / 7$ & 0 & 925.8 & 83.6 \\
\hline 5 & $3 / 8$ & 0 & 695.0 & 81.9 \\
\hline
\end{tabular}

Subsequent parametric tests also demonstrated that the variability in efficiencies caused by other factors such as coal moisture, excess $\mathrm{O}_{2}$, and air heater exit temperatures was greater than the variability induced by cofiring 4 percent biomass.

Cofiring did not impact emissions. $\mathrm{NO}_{\mathrm{x}}$ and $\mathrm{SO}_{2}$ emissions were monitored through the CEMS system, along with opacity. Variability in these emissions was sufficient to bracket the results obtained during the cofiring tests. Further, there was insufficient biomass in the fuel supply to create the types of combustion mechanisms conventionally associated with 
$\mathrm{NO}_{\mathrm{x}}$ reduction through cofiring. Based upon the favorable results experienced at Colbert Fossil Plant, TVA commercialized the cofiring operation at that location.

\section{Project $4-$ Switchgrass Testing at Blount St. Station of Madison Gas \& Electric}

No activity occurred on this project.

\section{Project 5 - High Percentage Cofiring with Southern Company}

No activity occurred on this project.

\section{Project 6 - Cofiring Testing at Michigan City Generating Station of NIPSCO}

The cofiring test at Michigan City was completed. As a follow-up, NIPSCO and FWDC pursued a more extensive test program for using biomass in a cyclone boiler. The utility chose the Bailly \#7 boiler as its candidate for a demonstration for the following reasons:

- $\quad$ Size (Bailly \#7 boiler is a $160 \mathrm{MW}_{\mathrm{e}}$ capacity unit)

- $\quad$ Presence of a scrubber, the Pure Air scrubber, to control $\mathrm{SO}_{2}$ emissions

The test concept at this cyclone boiler is firing a blend of biomass and petroleum coketwo opportunity fuels with distinctly different characteristics - with coal. The basis for this program comes from the characteristics of the fuels themselves, shown in Table 3.

Table 3. Complementary Characteristics of Biomass and Petroleum Coke

\begin{tabular}{|l|l|l|}
\hline \multicolumn{1}{|c|}{ Characteristic } & \multicolumn{1}{c|}{ Biomass (e.g., wood waste) } & \multicolumn{1}{c|}{ Petroleum coke } \\
\hline Heat content & Low (typically $5,000 \mathrm{Btu} / \mathrm{lb})$ & High (typically $14,500 \mathrm{Btu} / \mathrm{lb})$ \\
\hline Sulfur content & Low (typically $<0.02 \%)$ & High (typically $3 \%-6 \%)$ \\
\hline Ash content & Low (typically $<3 \%)$ & Low (typically $<0.5 \%)$ \\
\hline Fuel nitrogen & Low (typically $\left.0.4 \mathrm{lb} / 10^{6} \mathrm{Btu}\right)$ & $\begin{array}{l}\text { Lower than coal (typically }<1 \\
\left.\mathrm{lb} / 10^{6} \mathrm{Btu}\right)\end{array}$ \\
\hline Fuel volatility & Very high $\left(\mathrm{V} / \mathrm{FC}^{*}\right.$ ratios $\left.\cong 5.0\right)$ & Very low $(\mathrm{V} / \mathrm{FC} *$ ratios $\cong 0.05)$ \\
\hline Typical fuel cost & $\$ 1.50 / 10^{6} \mathrm{Btu}$ & $\$ 0.70 / 10^{6} \mathrm{Btu}$ \\
\hline$*$ V/FC is the volatile/fixed carbon ratio from the proximate analysis \\
\hline
\end{tabular}


The program is based upon the fact that blending these two fuels will maintain fuel quality relative to the existing coal, and will also reduce fuel nitrogen content relative to the existing coal as shown in Figures 1 and 2.

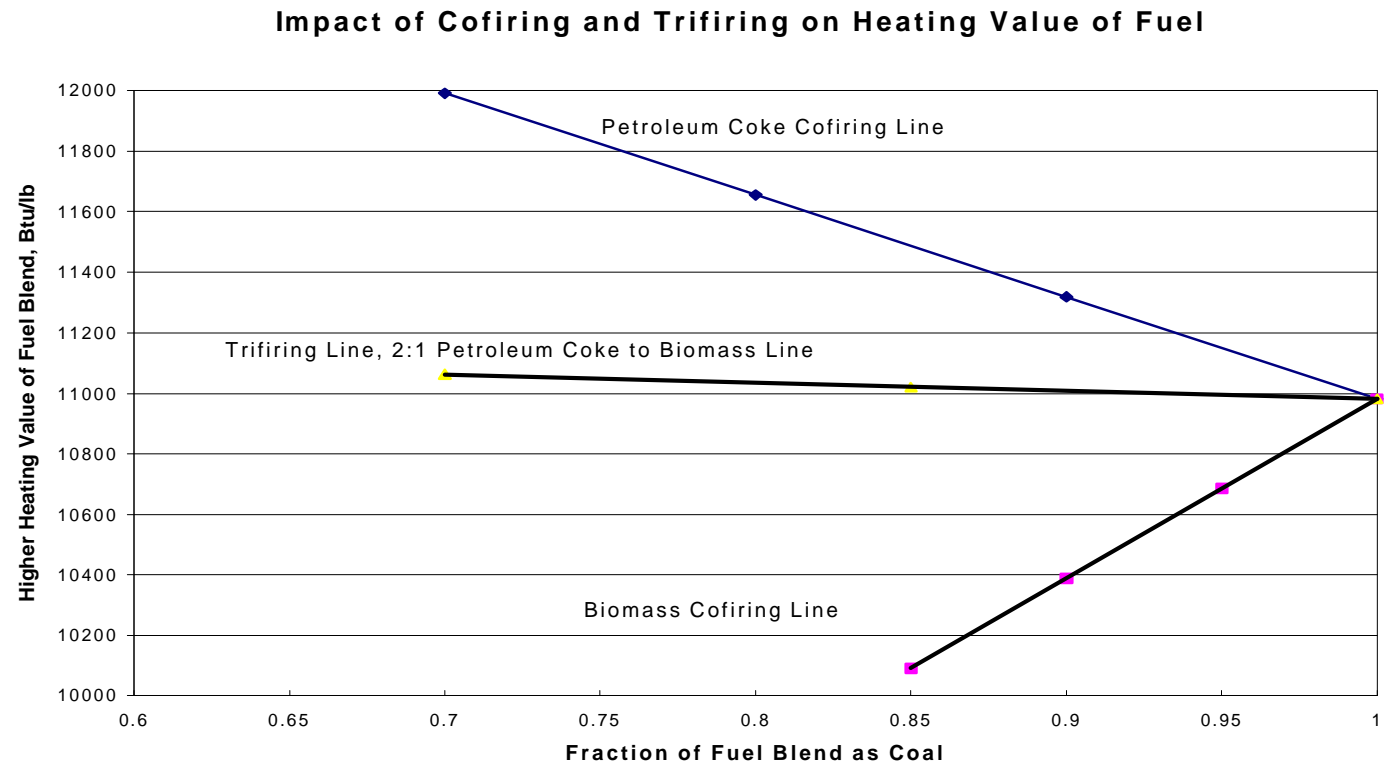

Figure 1. Impact of Firing Petroleum Coke and Biofuel on the Heating Value of the Fuel Blend

\section{Cofiring and Trifiring vs Fuel Nitrogen Content}

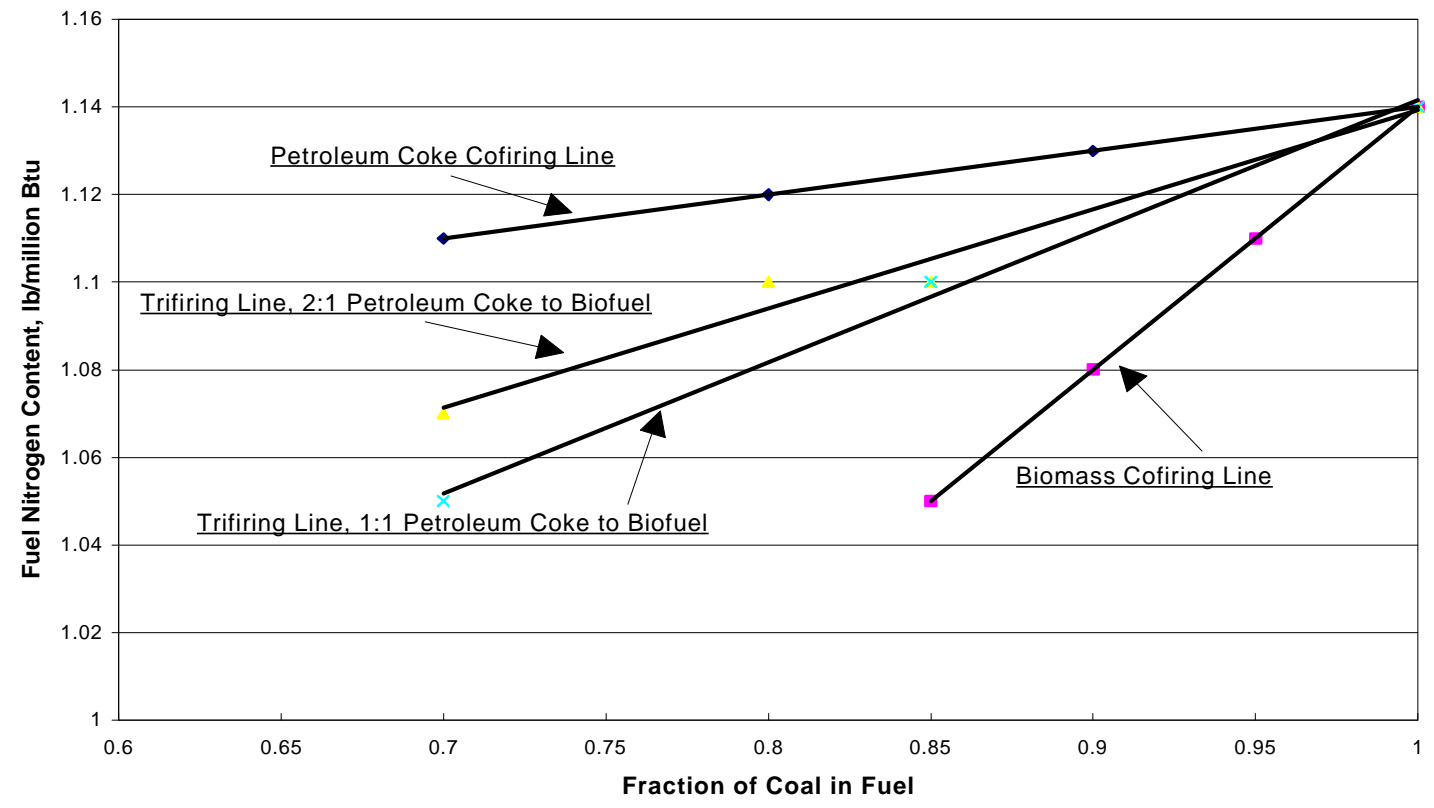

Figure 2. Fuel Nitrogen Content as a Function of Opportunity Fuel Blend 
. The scope of that program includes the following:

- $\quad$ design and installation of test apparatus, sufficiently rugged to withstand 9 to 12 months of continuous operations including during the winter months of Northern Indiana

- $\quad$ procurement of both clean urban wood waste and petroleum coke for blending on-site at the Bailly station

- baseline testing of the generating station, including balancing of the cyclones as appropriate, to determine the standard against which the opportunity fuels firing will be judged

- $\quad$ testing with biofuel and petroleum coke —separately — to determine specific combustion impacts of each of those fuels

- $\quad$ testing firing with various blends of petroleum coke and biofuel to determine the optimum fuel blend

- $\quad$ once the optimum blend has been determined, test the unit with that blend for at least 6 months in order to determine both the short and long term impacts associated with this cofiring program

- $\quad$ perform associated analytics to support the test program

- develop reports resulting from the test program.

The program, so identified, was initiated. Contractual and related matters have been started in order to ensure successful completion of the project.

\section{Project 7 - Testing Cofiring of Switchgrass by Nebraska Public Power District/Sandia}

No activity has occurred on this project

\section{Project 8 - Waste Plastics Cofiring at Duke Power}

No activity has occurred on this project 


\section{Project 9 - Plastics/Fiber/Pulp Waste Cofiring with SCE\&G}

No activity has occurred on this project

\section{Project 10 - Urban Wood Waste Cofiring in Pittsburgh, PA}

No activity has occurred on this project

\section{Project 11 - Toxic Emissions from Cofiring Evaluation}

No activity has occurred on this project

\section{Project 12 - Fuel/Powerplant Model Development}

Foster Wheeler Environmental Corporation completed its fluidized bed heat and mass balance combustion spreadsheet. Foster Wheeler Development Corporation continued its work on the cyclone model.

Foster Wheeler Development Corporation continued its assessment of the feasibility of cofiring at the Central \& Southwest Generating Stations: Northeastern \#3 and Pirkey. A kick-off meeting was conducted in February. Site walks were conducted at Northeastern and at Flint Creek. Fuel surveys were initiated for the Northeastern and Pirkey areas.

\section{Project $13-\mathrm{CO}_{2}$ Utilization in Algal Systems}

No activity occurred during this quarter.

\section{Project 14 - Combustion Tests and Combustor Development}

No activity occurred during this quarter.

\section{Project 15 - Support for Ash Sales from Cofiring Plants}

No activity occurred during this quarter.

\section{Project $16-\mathrm{CO}_{2}$ Capture and Disposal Options}

No activity occurred during this quarter. 


\section{REFERENCES}

Papers were given at the Clearwater Conference concerning the results of the Seward cofiring tests and the Michigan City cofiring tests. These papers are attached to this report. 


\title{
COFIRING WOOD WASTE WITH COAL AT THE SEWARD GENERATING STATION
}

\author{
David Tillman \\ Foster Wheeler Environmental Corporation \\ Joseph Battista \\ GPU Genco \\ Evan Hughes \\ Electric Power Research Institute
}

\begin{abstract}
In December, 1996 and July, 1997, The Electric Power Research Institute (EPRI), with support from the Federal Energy Technology Center (FETC), sponsored wood waste cofiring tests at the Seward Generating Station of GPU Genco. Some 20 parametric tests were conducted. These tests, conducted by Foster Wheeler Environmental Corporation, evaluated cofiring up to 10 percent (heat input basis) using wood wastes with various moisture and ash contents, and with varying fuel volatility. Fuel moisture contents ranged from 13 percent to over 50 percent. Ash contents ranged from $<1$ percent to 5 percent. Fuels ranged from kiln dried sawdust to $>2$ year old sawdust that had begun the process of devolatilization. The tests were conducted to examine the impact of biomass cofiring on boiler capacity, efficiency, stability, emissions, and potential problems associated with unburned carbon in the flyash and bottom ash. They were the first cofiring tests conducted on a wall-fired boiler using separate feed of wood waste into the unit. The cofiring technique involved screening all of the biofuel to $<1 / 4$ " particle size. The screened material was then transported to the burner and injected in the center of the coal flame. The biofuel did not go through the pulverizers on the way to the boiler, but was injected separately. Results of the testing documented the ability of cofiring to increase the capacity of the boiler when wet coal was encountered and the boiler normally experienced derating. The results of testing also documented modest impacts of cofiring on boiler efficiency, and only slight impacts of cofiring on unburned carbon. Impacts on emissions
\end{abstract}


were favorable with respect to $\mathrm{SO}_{2}$ and $\mathrm{NO}_{\mathrm{x}}$, with the latter impacts being caused by the fuel injection technique. This paper summarizes the results of the parametric tests, leading to the proposed program for longer term demonstration of cofiring at this location. 


\section{INTRODUCTION}

Cofiring wood waste with coal is frequently proposed as a means for addressing numerous economic and environmental issues: 1) meeting proposed portfolio standards for energy generation from renewable resources, 2) supporting economic development of utility customers as a means for maintaining load in deregulation, 3) reducing $\mathrm{SO}_{2}$ emissions by reducing the sulfur content of the fuel, and 4) reducing $\mathrm{NO}_{x}$ emissions. At the same time, it is recognized that cofiring can cause operational changes as a function of fuel considerations.

There are two methods to achieve cofiring: blending biofuel with coal on the coal pile, and sending the blend through the pulverizers to the boiler; or preparing the wood separately from the coal, and feeding the wood directly into the primary furnace. Each has advantages and disadvantages. Blending the coal and biofuel is inherently less capital intensive than separate feeding of the two fuels to the boiler. Initial tests at the Shawville Generating Station of GPU Genco demonstrated that this approach has economic consequences including significant loss of capacity and an increase in house load. Ball and race pulverizers used to feed wall-fired boilers experience increased feeder speeds as the bulk density and moisture content of the wood take a toll. Bowl mills used to feed tangentially-fired boilers experience a decrease in temperature as the biofuel moisture becomes significant. When the fuel was blended at 3 percent sawdust/97 percent coal (mass basis), the Shawville Generating Station experienced significant capacity losses in both Boiler \#2 (wall-fired) and Boiler \#3 (T-fired) as shown in Figures 1 and 2. Further, cofiring increased pulverizer amps as is shown in Figure 3. 


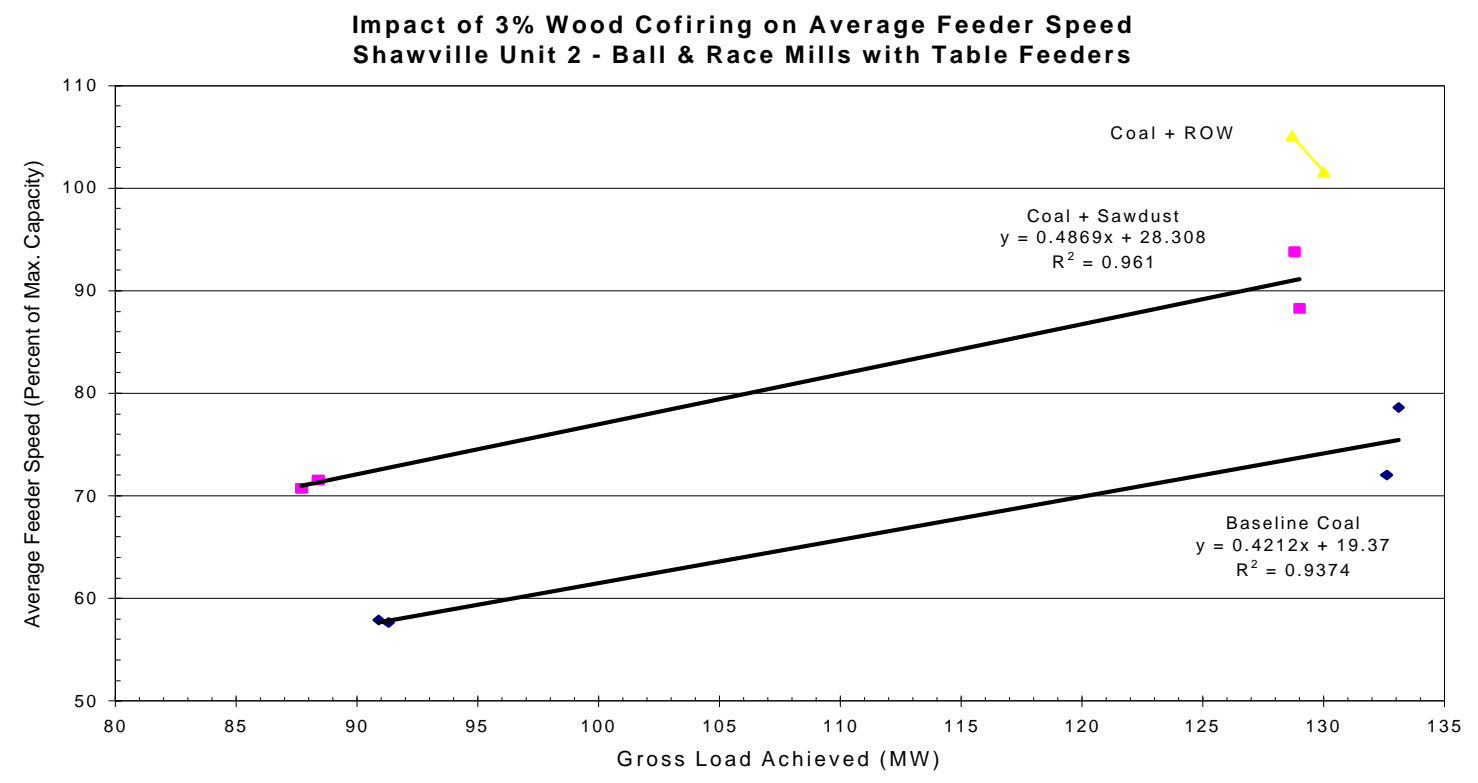

Figure 1. Impact of Blended Fuel Cofiring on Feeder Speeds at Shawville Generating Station Boiler \#2

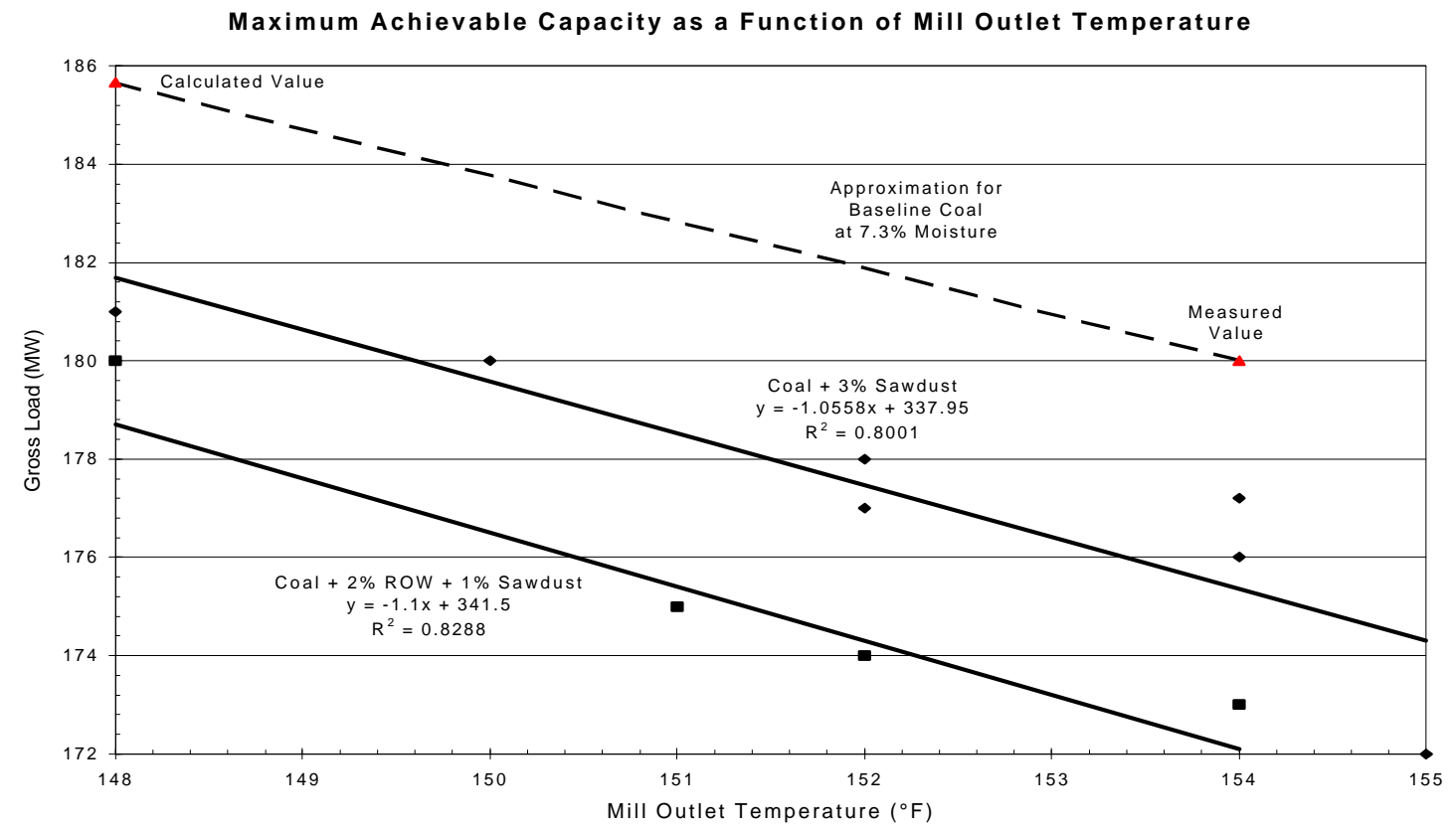

Figure 2. Impact of Blended Fuel Cofiring on Bowl Mill Temperatures and Capacity at the Shawville Generating Station 


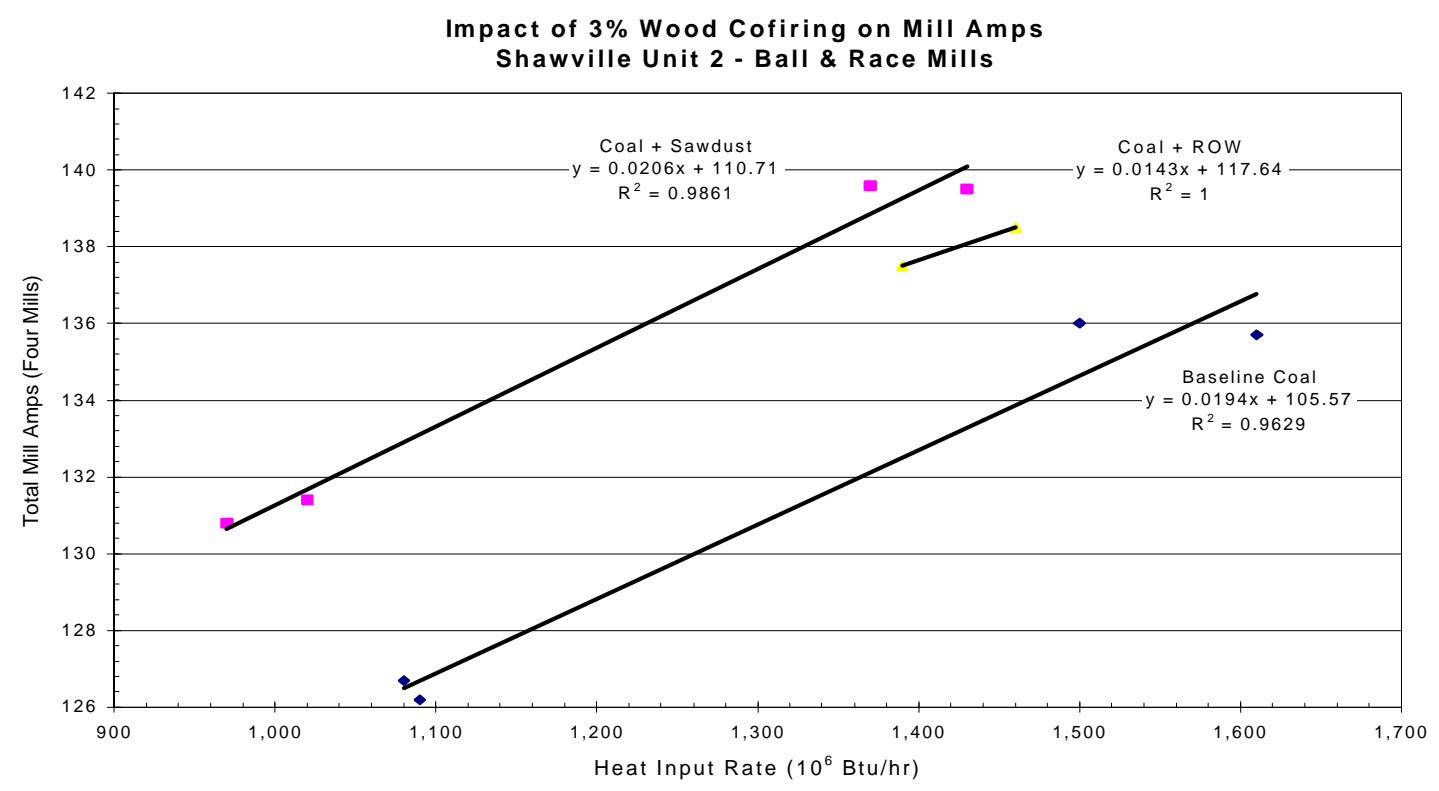

Figure 3. Impact of Blended Fuel Cofiring on Mill Amps at Shawville Generating Station Boiler \#2.

The results of the test program at Shawville demonstrated that, if a utility operates its boilers at the limit of pulverizer capacity, blended fuel cofiring in pulverized coal boilers has unacceptable consequences. GPU Genco and EPRI changed the focus of this cofiring program to the Seward Generating Station, and cofiring wood waste with coal using a separate feed system.

\section{TEST APPROACH AND METHODOLOGY FOR COFIRING AT SEWARD GENERATING STATION}

The cofiring program at Seward Generating Station involved designing and installing a system for separate injection of the biofuel. This system would then be used to test the implications of cofiring up to 20 percent (mass basis) sawdust with eastern bituminous coal.

\subsection{Test Equipment Apparatus}

Foster Wheeler developed a test system for GPU Genco, to be used for cofiring in the Seward \#12 boiler, a 330,000 lb/hr wall-fired unit with two rows of burners. Each row of burners contained 3 conventional PC burners with Eagle Air registers. The concept of this cofiring system involved screening the wood in a trommel screen to ensure $<1 / 4$ " biofuel 
particles, a surge bin, 3 lockhoppers, and 3 blowers. Each blower transported the biofuel from a single lockhopper to a burner on the top row of coal burners.

The biomass was not mixed with coal in the burner. Rather, the sawdust was blown down the centerpipe of the burner and then diffused into the coal flame in the furnace. The modifications to the burner included flexible piping to connect the wood transport system to the centerpipe of the burner, and diffusers in the end of the centerpipe to transport the sawdust into the coal flame. Air flow was held constant, to achieve a velocity of 5,000 $\mathrm{ft} / \mathrm{min}$. Biofuel feed rates were changed using variable speed screws in the surge bin, feeding the lockhoppers. The arrangement of the bin, blowers, and lockhoppers is shown in Figure 4. The burner modification and diffuser design is shown in Figure 5.

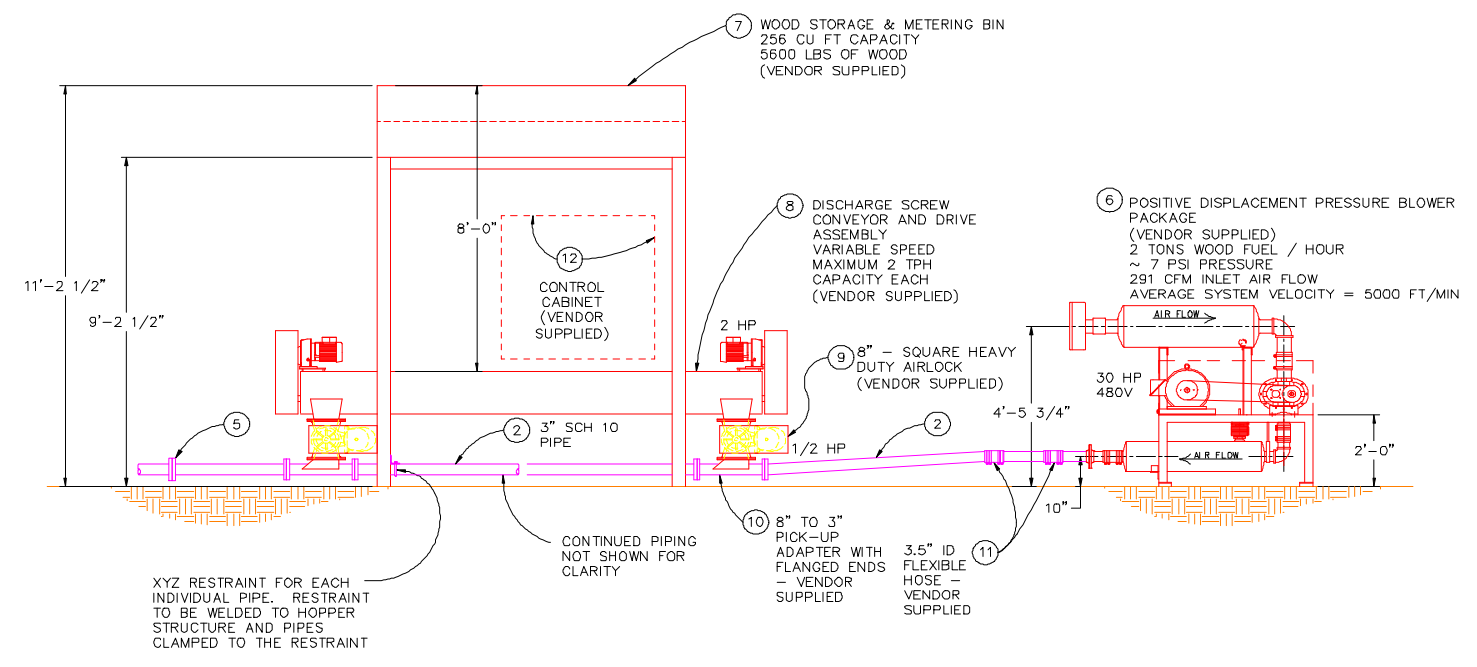

Figure 4. Elevation view of Wood Transport System. 


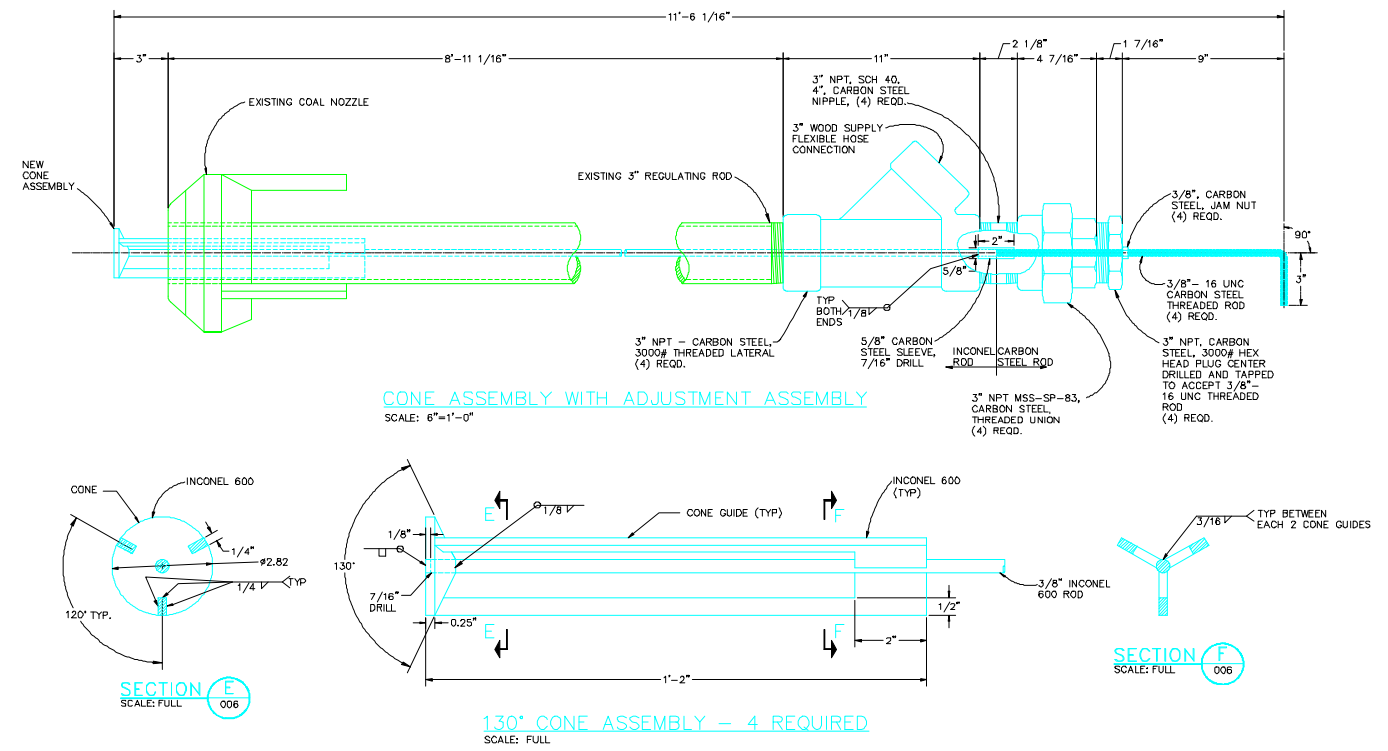

Figure 5. Biofuel Diffusers Used at the Seward Generating Station Cofiring Tests

The characteristics of this feed system included the ability to vary the biofuel feed to each burner, the ability to cofire without impacting the coal delivery system, and the ability to measure the flow of wood waste to the boiler at any given time. This system permitted instantaneous fuel feeding at known rates, a major advantage for test purposes.

\subsection{Test Methodology}

Two sets of tests were conducted with this apparatus: tests in Dec, 1996 and in July, 1997. These tests addressed issues of capacity, efficiency, and the management of emissions. Within the context of efficiency, these tests addressed critical concerns of unburned carbon in the bottom ash and flyash, and the potential for glowing embers or "fireflies" being carried out of the furnace. Tests were conducted with three types of sawdust: fresh green ( $\sim 40$ percent moisture) sawdust, dry ( 13 percent) sawdust and shavings, and old (>1 yr) old wet sawdust approaching 50 percent moisture.

The test methodology was based upon constructing detailed heat and material balances about the boiler for each test. Fuel samples were obtained of all biofuels, and for all coal used during the test periods. These samples were characterized at Hazen Research in Golden, CO; the basic fuel chemistry was determined by these tests. Flyash samples were obtained by traversing the air heater exit duct, and passing the captured gaseous combustion products through a thimble sampler. Bottom ash samples were obtained by a plant device that reached all portions of the ash pit. Flyash and bottom ash samples were 
also sent to Hazen Research for unburned carbon and loss on ignition (LOI)

determination. Fireflies were evaluated by videotaping the gaseous combustion products entering the air heater, and then counting the number of glowing embers per minute as a function of test conditions.

Characterization of the gaseous combustion products was performed at the inlet and the outlet of the air heater. This characterization obtained concentrations of $\mathrm{CO}_{2}, \mathrm{CO}$, and $\mathrm{O}_{2}$ in the gas stream; values were obtained on a dry basis, and were used to characterize air heater leakage. Control room data were obtained to characterize the performance of the boiler under baseline and cofiring conditions. Such data included feedwater pressure, temperature, and flow; main steam pressure, temperature, and flow; pulverizer amps and feeder speeds; $\mathrm{O}_{2}$ at the entrance to the air heater; combustion air temperatures; and temperatures of the gaseous combustion products entering and exiting the air heater. The data were manually recorded every 10 minutes during the test periods.

Boiler \#12 and boiler \#14 are ducted to a common stack. However, the plant has continuous emissions monitoring on each unit to determine the source of any problems. Those emissions monitoring data were obtained and used to evaluate opacity and $\mathrm{NO}_{\mathrm{x}}$ emissions associated with cofiring.

All of the data were used to develop heat and material balances for each test. These heat and material balances were developed using the "losses" method, and solving for coal flow. Extensive calibration of the biofuel feed bin, and the variable speed augers, made such an approach most practical. Emissions results were obtained directly from plant instrumentation, and then correlated to test conditions.

\section{RESULTS OF THE SEWARD CORIRING TESTS}

The Seward cofiring tests provided an evaluation of the impact of separately injecting sawdust into the \#12 boiler on unit capacity, boiler efficiency, and formation of airborne emissions. The general results were sufficiently favorable that GPU Genco is pursuing a 3 -year demonstration of this technology.

\subsection{Capacity Implications of Cofiring at Seward Generating Station}


The results of cofiring on boiler capacity were very favorable, particularly when the unit was firing wet coal. Wet coal is a common phenomenon during winter months in the Northeast.

During the December, 1996 test period, a set of capacity tests was conducted. The unit was being fired with wet coal, and was capacity limited. The operators brought Boiler \#12 to maximum achievable capacity $\left(247.9 \times 10^{3} \mathrm{lb}\right.$ steam) on coal, and then introduced the wet sawdust at 18.9 percent of the mass fuel feed, or about $\sim 6.5$ percent of the Btu fuel feed to the unit. The maximum achievable unit capacity increased to $282 \times 10^{3} \mathrm{lb}$ steam.

The Seward \#12 boiler, along with \#14 boiler, feeds a $64 \mathrm{MW}_{\mathrm{e}}$ turbine with a steam rate of $\sim 10.5 \mathrm{lb} / \mathrm{kWh}$. The addition of biofuel, then increased the capacity of the unit by about $3.2 \mathrm{MW}_{\mathrm{e}}$, or about 10 percent of the capacity resulting from Boiler \#12.

\subsection{Efficiency Impacts of Cofiring}

Efficiency impacts of cofiring revolve around the impacts of biomass on the moisture and ash contents of the total fuel feed, the impacts of biomass on the heat content of the total fuel feed, and related concerns. The tests conducted in July 1997 illustrate the impact of cofiring on efficiency. Because the calculations are based on composition of the various fuels, they are presented in Table 1.

Table 2 presents efficiency results, including unburned carbon in the flyash. These efficiencies were calculated using the conventional heat loss methodology. Table 2 also illustrates the impact of cofiring on What becomes apparent from the data is the fact that cofiring does impact boiler efficiency. Table 2 does not present data concerning CO emissions, excess $\mathrm{O}_{2}$ requirements, air heater exit temperatures, air heater inleakage, or related parameters governing boiler efficiency. These parameters were measured during the cofiring tests. $\mathrm{CO}$ emissions were a constant $<20$ ppmv regardless of fuel. $\mathrm{O}_{2}$ measurements were typically slightly lower when cofiring than when using 100 percent coal. Air heater exit temperatures and air heater inleakage levels were not impacted by cofiring. 
Table 1. Analysis of Fuels Burned at the Seward Generating Station Tests

Parameter

Proximate Analysis (Wt \%)
Fuel 
Table 2. Boiler Efficiency Results at the Seward Generating Station Tests, July 1997

\begin{tabular}{|c|c|c|c|c|c|c|}
\hline \multirow{3}{*}{$\begin{array}{c}\text { Test No } \\
1\end{array}$} & \multirow{3}{*}{$\begin{array}{l}\text { Wood Type } \\
\text { None }\end{array}$} & \multicolumn{2}{|c|}{$\begin{array}{c}\text { Cofiring } \\
\text { Percentage }\end{array}$} & \multirow{3}{*}{$\begin{array}{c}\begin{array}{c}\text { Boiler } \\
\text { Efficiency }\end{array} \\
\text { (Percent) }\end{array}$} & \multirow{2}{*}{\multicolumn{2}{|c|}{$\begin{array}{l}\text { Unburned Carbon in } \\
\text { Flyash } \\
\left.\text { (lb/10 }{ }^{6} \text { Btu or } \mathrm{kg} / \mathrm{GJ}\right)\end{array}$}} \\
\hline & & \multirow{2}{*}{$\begin{array}{c}\text { Mass } \\
0\end{array}$} & \multirow{2}{*}{$\frac{\text { Heat }}{0}$} & & & \\
\hline & & & & & 0.95 & $(0.41)$ \\
\hline 2 & FGS $\left(^{*}\right)$ & 3.4 & 1.47 & 85.79 & 0.85 & $(0.37)$ \\
\hline 3 & $\mathrm{FGS}\left({ }^{*}\right)$ & 6.4 & 2.83 & 85.71 & 0.85 & $(0.37)$ \\
\hline 4 & FGS $\left(^{*}\right)$ & 9.5 & 4.31 & 85.47 & 0.83 & $(0.36)$ \\
\hline 5 & FGS $\left(^{*}\right)$ & 13 & 6.04 & 85.03 & 0.83 & $(0.36)$ \\
\hline 6 & FGS $\left(^{*}\right)$ & 16.1 & 7.60 & 84.21 & 0.80 & $(0.34)$ \\
\hline 7 & DSS $\left(^{*}\right)$ & 13.8 & 8.11 & 85.74 & 0.82 & $(0.35)$ \\
\hline 8 & DSS $\left(^{*}\right)$ & 17.2 & 10.3 & 84.09 & 0.78 & $(0.34)$ \\
\hline 9 & FGS $\left(^{*}\right)$ & 17.9 & 8.53 & 84.65 & 0.80 & $(0.34)$ \\
\hline 10 & OS $\left(^{*}\right)$ & 4.4 & 1.61 & 86.13 & 0.87 & $(0.37)$ \\
\hline 11 & OS $\left(^{*}\right)$ & 8.2 & 3.05 & 85.26 & 0.85 & $(0.37)$ \\
\hline 12 & OS $\left(^{*}\right)$ & 11.9 & 4.31 & 85.62 & 0.84 & $(0.36)$ \\
\hline 13 & None & 0 & 0 & 86.07 & 0.87 & $(0.37)$ \\
\hline
\end{tabular}

(*) FGS is fresh green sawdust at $38.8 \%$ moisture, DSS is dry shavings and sawdust at $13.5 \%$ moisture, and OS is old sawdust at $48.5 \%$ moisture.

Figure 6 illustrates the general impact of cofiring on efficiency. Further, as shown in Figure 6, the loss in efficiency is impacted by changes in excess $\mathrm{O}_{2}$, air heater exit temperatures, and related concerns as well as by cofiring. While the cofiring trendline has a reasonable correlation $\left(r^{2}=.84\right)$, there is ample room for other influences unrelated to cofiring. Figure 7 demonstrates that the impact of cofiring on unburned carbon is not significant. While there is a general upward trend in unburned carbon in the flyash as a function of cofiring, the spread in data points is sufficient to point out that the trend is heavily influenced by other factors (e.g., excess $\mathrm{O}_{2}$, residence time in the primary furnace). Unburned carbon values, in any event, are acceptable for a boiler of this age.

Fireflies or glowing embers also indicate unburned carbon problems. Figure 8 presents the production of glowing embers as a function of cofiring level using green sawdust as the 
biofuel. Its results are representative of the issue. Note that, for the range of conditions during the cofiring test, burning carbon particles were not problematical.

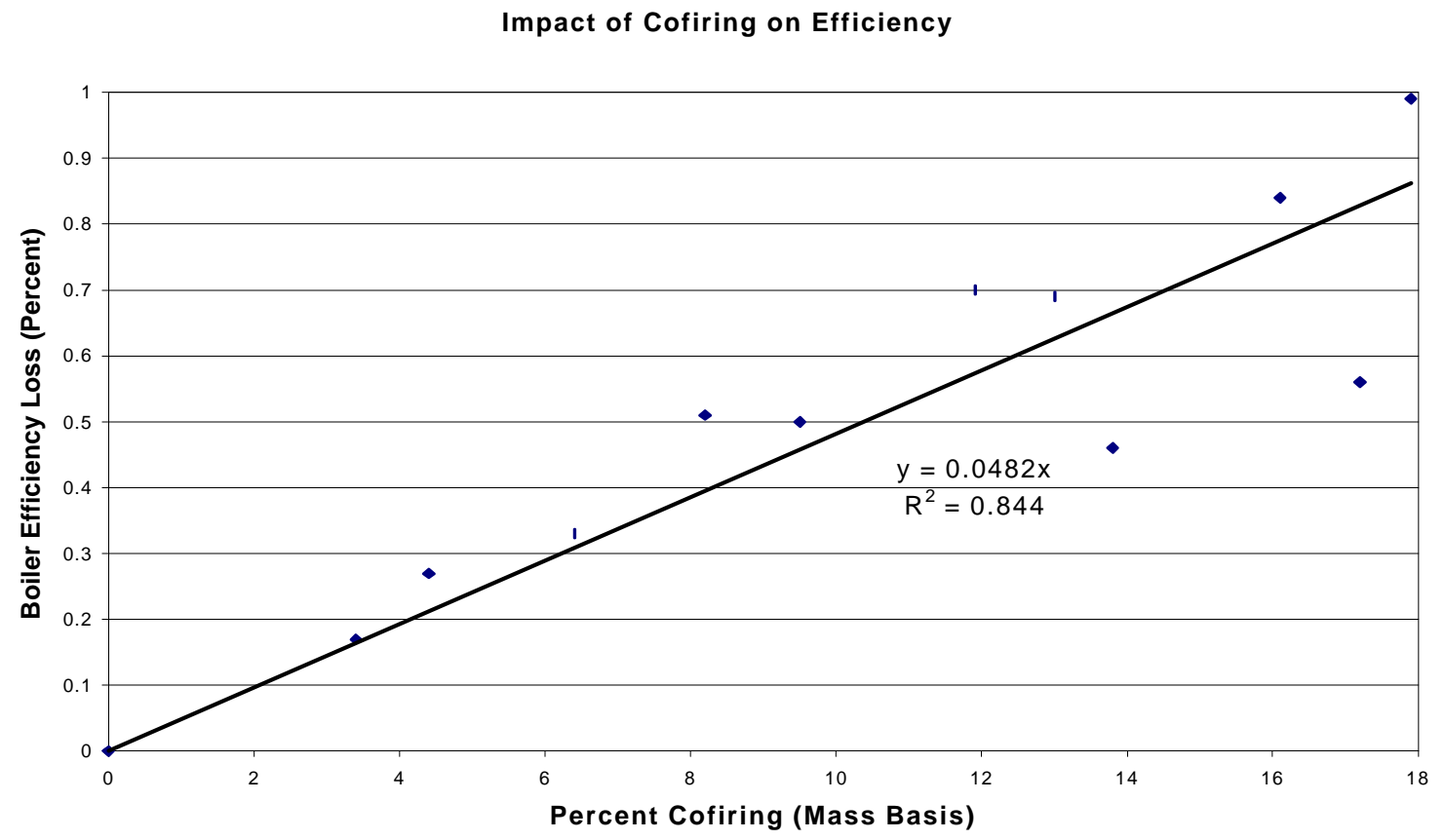

Figure 6. Impact of Cofiring on Boiler Efficiency

Cofiring Impacts on Unburned Carbon in the Flyash

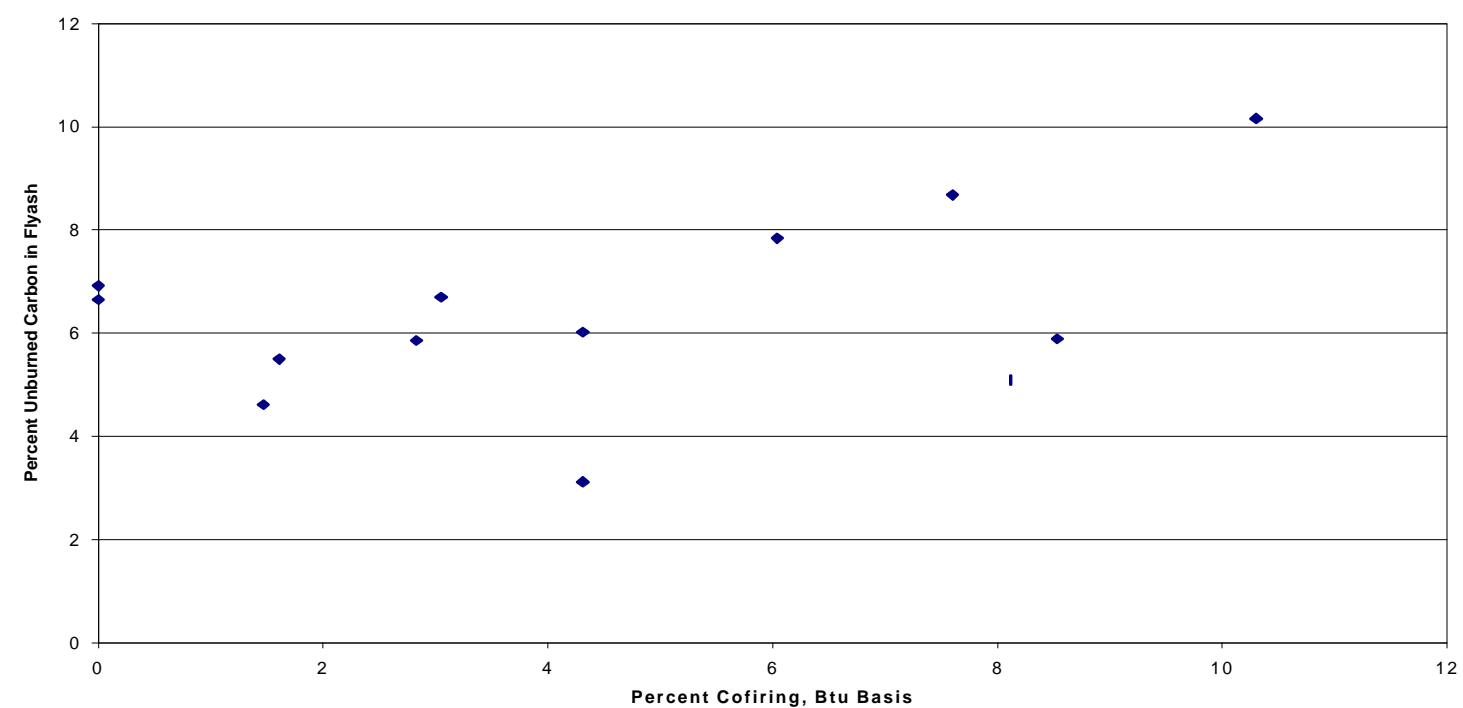


Figure 7. Impact of Cofiring on Unburned Carbon in the Flyash

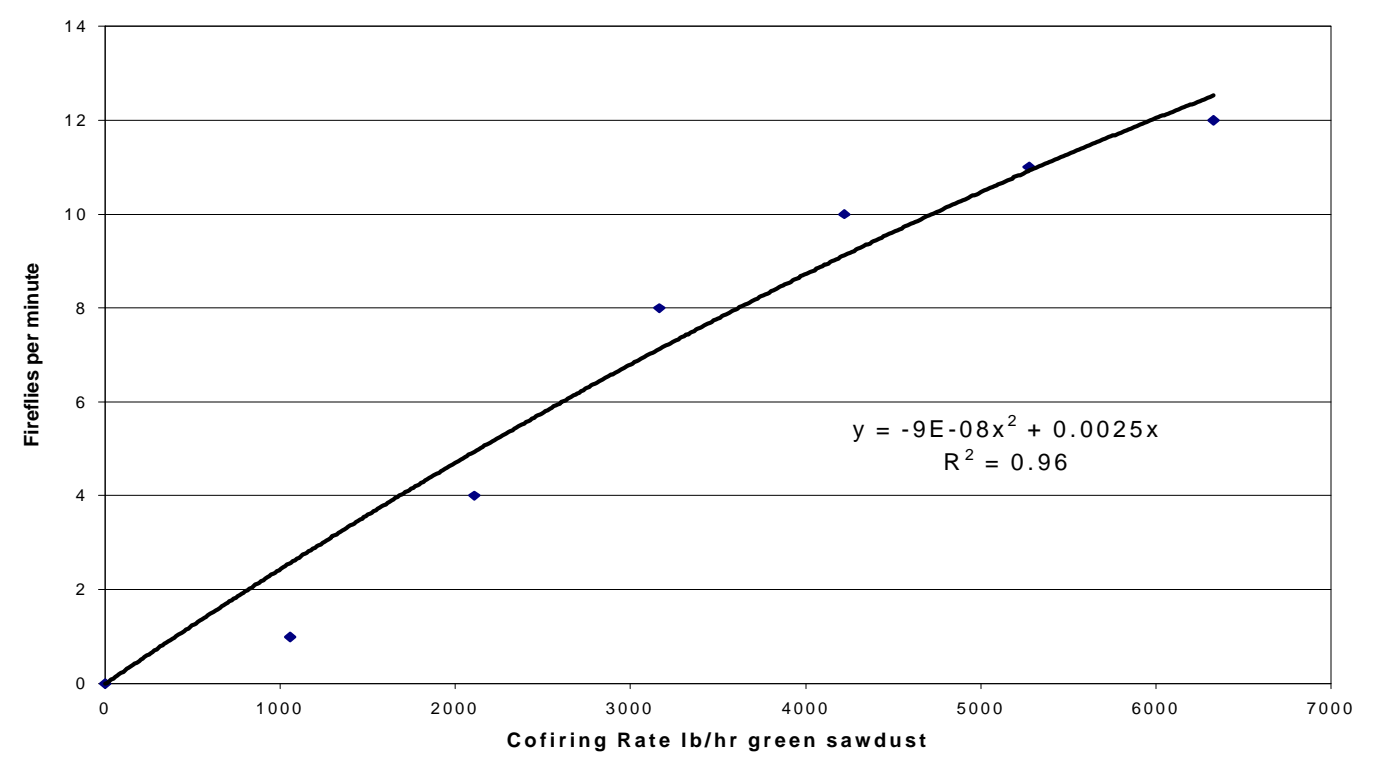

Figure 8. The Production of Glowing Embers as a Function of Cofiring Conditions.

The optimum cofiring percentage for this boiler is in the 10 to 12 percent (mass basis) region. Under those conditions, the boiler efficiency loss is about 0.5 percent. Efficiency is viewed as an economic number. It sets an upper limit on the price that can be paid for biofuel. For a unit with a net station heat rate of about $14,200 \mathrm{Btu} / \mathrm{kWh}$, the efficiency loss of 0.5 percent is acceptable if reflected in the price of wood.

\subsection{Emissions Impacts of Cofiring at Seward Generating Station}

The most favorable impacts of cofiring are considered to be environmental: avoiding landfilling of wood waste, reducing sulfur and nitrogen oxides, and reducing greenhouse gases such as fossil-based $\mathrm{CO}_{2}$. Emissions data were obtained from the plant emissions monitoring system installed on Boiler \#12. This system is identical to a CEMS, except that it is not certified because Boilers \#12 and \#14 share a common stack.

Opacity emissions tended to creep upward with increased levels of cofiring, although the trend is far from statistically significant. Opacity may ultimately set a limit on cofiring percentage, depending upon the quality of the biofuel; however that limit is above 20 percent by mass, or 10 percent by heat. $\mathrm{CO}$ emissions always were below 20 ppmv, indicating no problem with combustion completeness. Fossil $\mathrm{CO}_{2}$ emissions were reduced 
as a function of biofuel substitution on a Btu basis, adjusting for efficiency losses. Typical percentage reductions of fossil $\mathrm{CO}_{2}$ were on the order of 5 to 8 percent.

Sulfur dioxide emissions were reduced as a function of the cofiring percentage expressed on a Btu basis. The wood waste is essentially free of sulfur (see Table 1). The substitution of wood for coal reduces $\mathrm{SO}_{2}$ emissions. While there is some speculation that the alkalinity of wood ash may further reduce sulfur emissions, this phenomenon was not experienced at the Seward cofiring tests.

$\mathrm{NO}_{\mathrm{x}}$ emissions were reduced by cofiring, and by mechanisms that went well beyond reducing fuel nitrogen or flame temperature. Figure 9 illustrates the decrease in $\mathrm{NO}_{\mathrm{x}}$ formation as a function of cofiring. Note that the cofiring percentage is expressed on a mass basis, rather than a Btu basis. Figure 10 illustrates the decrease in NOx formation as a function of cofiring, using a Btu basis for percentage wood in the fuel to the boiler.

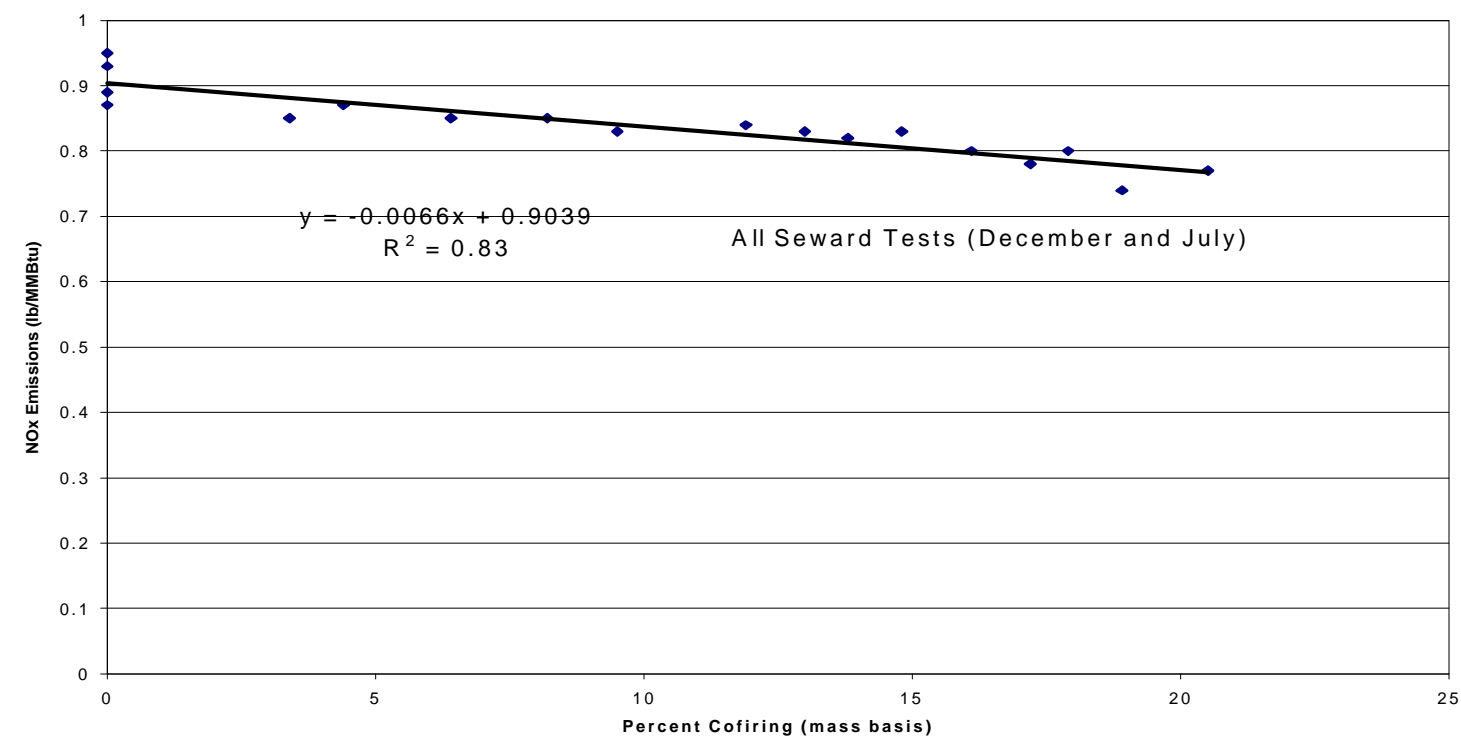

Figure 9. $\mathrm{NO}_{\mathrm{x}}$ Emissions as a Function of Biomass Cofiring (mass basis) 


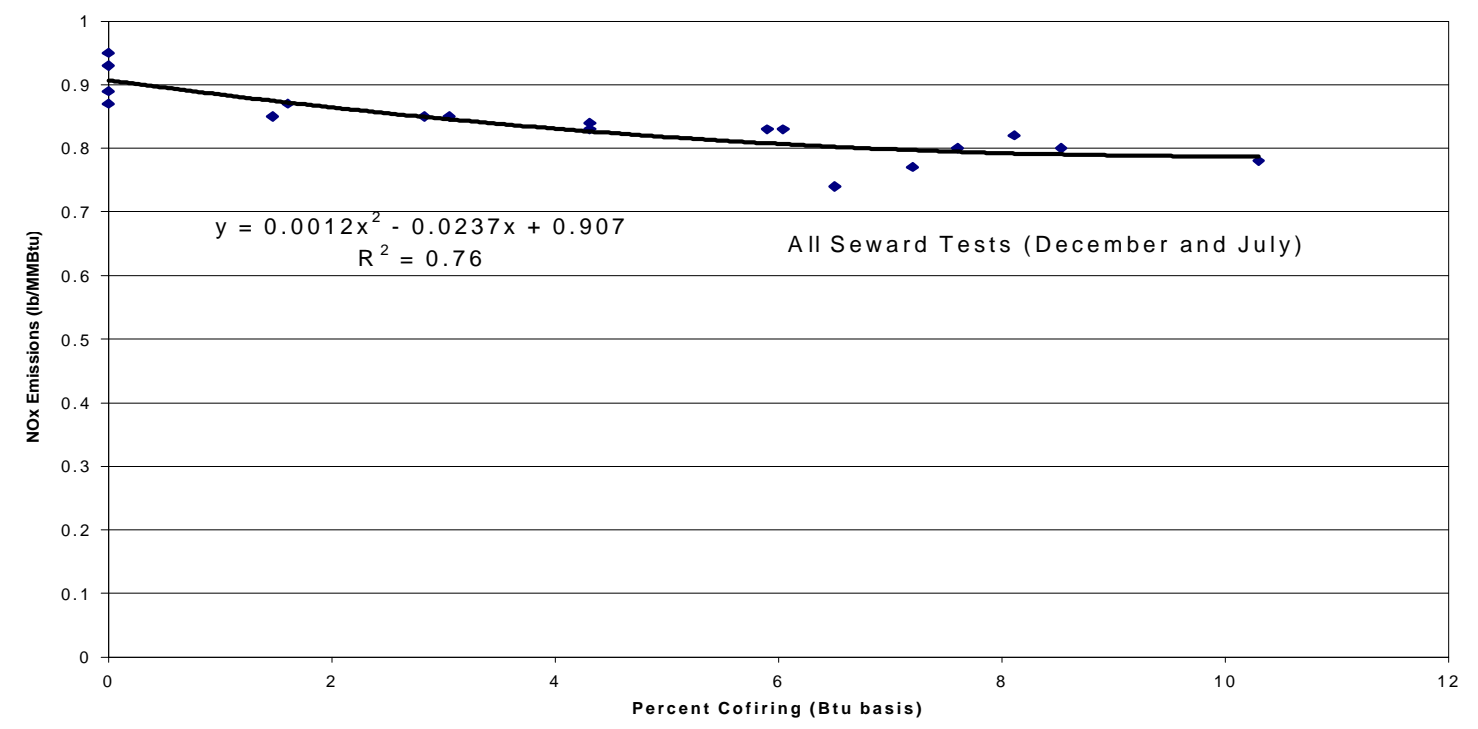

Figure 10. Impact of Biomass Cofiring on $\mathrm{NO}_{\mathrm{x}}$ Emissions (Btu basis)

It is significant that the wood waste was also essentially nitrogen free; consequently the percent cofiring reduced fuel nitrogen, in $1 \mathrm{~b} / 10^{6} \mathrm{Btu}$, by the following trend:

$$
\mathrm{FN}=1.02-.0086(\mathrm{C} \%)
$$

where $\mathrm{FN}$ is fuel nitrogen, expressed in $\mathrm{lb} / 10^{6} \mathrm{Btu}$ and $\mathrm{C} \%$ is cofiring percentage on a Btu basis. This equation is based upon calculations developed from fuels data, and is virtually a machine function. NOx emissions as a function of fuel nitrogen can be evaluated by the following regression equation:

$$
\mathrm{NO}_{\mathrm{x}}=0.256+0.583(\mathrm{FN})
$$

where $\mathrm{NO}_{\mathrm{x}}$ is the emissions measured in $\mathrm{lb} / 10^{6} \mathrm{Btu}$. However the $\mathrm{r}^{2}$ for this equation is only 0.24 . Cofiring does more than reduce fuel nitrogen.

The most probable mechanism identified to define the means for NOx reduction through cofiring is based not only on the Seward Generating Station tests, but also the tests sponsored by EPRI and conducted at Blount St. Station of Madison Gas \& Electric, the cofiring tests conducted at the Allen Fossil Plant, Kingston Fossil Plant, and Colbert Fossil Plant; these tests were sponsored by TVA and EPRI. All of these tests point to the fact that the biofuel, being more volatile, also ignites at a lower temperature. In igniting at a lower temperature it promotes coal ignition in a reducing environment, thereby adding to 
$\mathrm{NO}_{\mathrm{x}}$ control through inherent combustion staging. The tests at Seward Generating Station, where the wood was injected into the center of the coal flame, highlighted this mechanism.

The $\mathrm{NO}_{\mathrm{x}}$ emissions reduction achieved by cofiring was not sufficient to warrant use of this technology for the sole purpose of minimizing oxides of nitrogen. At the same time it does provide an environmental and economic benefit for this technique.

\section{CONCLUSION}

The cofiring tests at Seward Generating Station were most successful. They demonstrated that cofiring biofuel in a wall fired boiler, using separate feeding of wood waste and coal, could increase the capacity of the unit when firing wet coal. Efficiency losses were acceptable depending upon fuel price; and the determinants of efficiency (e.g., $\mathrm{O}_{2}$, air heater exit temperature) were not influenced by the practice of cofiring. Emissions reductions occurred for $\mathrm{SO}_{2}$, fossil $\mathrm{CO}_{2}$, and $\mathrm{NO}_{\mathrm{x}}$. The mechanisms for these reductions included fuel substitutions and changing the combustion characteristics at the point of ignition. These results were sufficiently favorable to support pursuing a 3-year demonstration of this cofiring technology. 


\title{
COFIRING URBAN WOOD WASTE WITH POWDER RIVER BASIN COAL AT THE MICHIGAN CITY GENERATING STATION
}

\author{
David Tillman \\ Foster Wheeler Development Corporation \\ James Campbell \\ Robert Stahl \\ Kristin Therkelsen \\ Foster Wheeler Environmental Corporation \\ Christine Newell \\ Northern Indiana Public Service Company \\ Evan Hughes \\ Electric Power Research Institute
}

\begin{abstract}
Northern Indiana Public Service Co. (NIPSCO) and the Electric Power Research Institute (EPRI), with support from the Federal Energy Technology Center (FETC), sponsored cofiring tests of urban wood waste with Powder River Basin (PRB) coal at the Michigan City Generation Station Boiler \#12. Michigan City Boiler \#12 is a supercritical unit generating $3.25 \times 10^{6} \mathrm{lb} / \mathrm{hr}$ of $3500 \mathrm{psig} / 1000^{\circ} \mathrm{F} / 1000^{\circ} \mathrm{F}$ steam for the generation of 469 $\mathrm{MW}_{\mathrm{e}}$. The test was unique in several respects: cofiring with PRB coal; preblending wood waste and coal, and storing the blend for 4 months; and cofiring in a supercritical boiler. Further, it was the most extensive test involving urban wood waste. Some 1,000 tons of biofuel were cofired with a blend of Black Thunder (PRB) and Shoshone coal. Data were obtained for an evaluation of the impacts of cofiring on unit capacity, stability, efficiency, and the formation of emissions.
\end{abstract}

The test results demonstrated that cofiring could be accomplished, and that there were no technical fatal flaws to deploying this technology. At the same time the test program documented impacts of cofiring on boiler capacity, efficiency, and emissions. Capacity 
can be impacted when the boiler is clean; however after the boiler has returned from an outage and run for several months, there is no capacity impact. Efficiency is impacted by cofiring; this reduces the economic value of the biofuel. Virtually all emissions are reduced by cofiring, and significant environmental benefits can be obtained in this area. The paper below summarizes the tests and associated results. 


\section{INTRODUCTION}

Northern Indiana Public Service Company (NIPSCO), working with the Electric Power Research Institute (EPRI) in a Tailored Collaboration (TC) agreement, pursued cofiring at its cyclone boilers as a means for addressing the following issues:

- $\quad$ achieving some measure of $\mathrm{NO}_{\mathrm{x}}$ reduction through the combustion process

- achieving significant greenhouse gas reductions, specifically fossil $\mathrm{CO}_{2}$

- $\quad$ supporting local customers in the management of urban wood wastes

The program was initiated by conceptual engineering reviews at three generating stations: Michigan City, Schahfer, and Bailly. The boilers at Michigan City and Schahfer stations are virtually identical supercritical cyclone units; they are $430-469 \mathrm{MW}_{\mathrm{e}}$ in capacity and are fired with a blend of Powder River Basin and Western Bituminous coals. These were the last cyclone boilers installed, being commissioned in 1974-5. The boilers at Bailly are considerably smaller, and are fired with Illinois Bituminous coal. The biomass resource in the area focuses upon urban wood waste: broken pallets at the steel mills, utilitygenerated wood wastes such as reels and pallets, clean construction and demolition waste, and like products. The resource also includes sawdust, shavings, and other materials from sawmills, mobile home manufacturers, furniture plants, and other wood processing industries.

The Michigan City Generating Station was chosen as the most suitable cofiring location for initial analyses. It has ample space in the coal yard to support cofiring, it has experience with fuel blending, it is highly instrumented, and conceptual engineering studies indicated that a cofiring facility could be installed for about $\$ 50 / \mathrm{kW}$ to $\$ 75 / \mathrm{kW}$ supported by biofuel. Further, because the Michigan City Generating Station is ISO 14000 certified, it has procedures in place to manage projects of this nature.

Once Michigan City had been selected, the parameters of a test program were identified. A test program and test plan was constructed, and was subsequently implemented.

\section{CHARACTERISTICS OF THE TEST PROGRAM}


The Michigan City Boiler typically burns a fuel blend of 60 percent Black Thunder (PRB) coal and 40 percent Shoshone coal. When Black Thunder is not available, other PRB coals are substituted including Caballo Rojo coal. The test program was designed to illustrate the impacts of substituting 10 percent urban wood waste and kiln dried sawdust into the blend, such that the final fuel product would be 50 percent PRB/40 percent Shoshone/10 percent biofuel. Key elements of the test program involved:

- $\quad$ receiving of the biofuel on-site

- $\quad$ on-site screening of the biofuel using a large shaker screen to particle sizes $<1 / 2$ ", with rescreening of the reject pile for additional product recovery

- $\quad$ blending of the biofuel with Shoshone coal on a 1:1 volume basis, yielding a mass ratio of 20 percent wood waste/80 percent Shoshone coal

- $\quad$ storing the blend of wood waste and Shoshone coal for 4 months

- $\quad$ cofiring the blend of coals and wood waste operating the boiler at minimum load and at full load, and varying the excess $\mathrm{O}_{2}$ parameter to determine the impact on $\mathrm{NO}_{\mathrm{x}}$ emissions

- $\quad$ cofiring tests were compared to baseline tests, where the coal blend was the only fuel fired; due to transportation difficulties, the baseline tests were conducted with Caballo Rojo coal while the cofiring tests were conducted with Black Thunder coal, and the results were adjusted mathematically to determine impacts

During the cofiring tests, the boiler remained in commercial operation. While load was set by plant operations, and held constant, no other special provisions were made. The boiler was not taken off line and cleaned prior to the testing. Air distribution to the cyclones was not adjusted. Because of these factors, and the consequence of burning PRB and Western coals, the boiler was derated to $430 \mathrm{MW}_{\mathrm{e}}$. Capacity limitations were associated with economizer exit temperatures. Table 1 identifies the 9 cofiring tests conducted at Michigan City Generating Station. 
Table 1. Cofiring Conditions for the Nine Tests Conducted

\begin{tabular}{|c|c|c|c|c|c|c|c|c|c|}
\hline \multicolumn{10}{|c|}{ Test } \\
\hline Parameter & 1 & 2 & 3 & 4 & 5 & 6 & 7 & 8 & 9 \\
\hline Date & $9 / 23$ & $9 / 24$ & $9 / 24$ & $9 / 24$ & $9 / 25$ & $9 / 25$ & $9 / 25$ & $9 / 26$ & $9 / 26$ \\
\hline Start Time & 1400 & 0400 & 0915 & 1700 & 0400 & 0900 & 1400 & 0715 & 1030 \\
\hline End Time & 1800 & 0700 & 1015 & 2000 & 0645 & 1200 & 1645 & 1015 & 1300 \\
\hline Load & 425.7 & 306.0 & 426.6 & 425.8 & 306.4 & 425.9 & 424.7 & 424.3 & 424.6 \\
\hline $\mathrm{MW}_{\mathrm{e}}$ & 3 & 8 & & 5 & 2 & 2 & 5 & 8 & 4 \\
\hline $\begin{array}{r}\text { Percent } \\
\text { Cofire }\end{array}$ & 0 & 0 & 0 & 10 & 10 & 10 & 10 & 10 & 10 \\
\hline $\begin{array}{r}\text { Main Steam } \\
\text { Flow kpph }\end{array}$ & 2914 & 2015 & 2918 & 2878 & 2020 & 2880 & 2881 & 2865 & 2872 \\
\hline $\mathrm{O}_{2}$ Percent & 2.42 & 2.79 & 2.40 & 2.48 & 2.88 & 2.82 & 2.38 & 2.42 & 2.29 \\
\hline
\end{tabular}

The combustion tests, themselves, involved developing data sufficient for analysis of boiler stability with and without cofiring, construction of heat and material balances, evaluation of feeder performance, evaluation of emissions, evaluation of ash quality, and evaluation of system temperature profiles. Fuel samples were obtained for the purpose of characterizing each fuel. Flyash samples were obtained to determine the impact of cofiring on unburned carbon and ash composition. Gaseous combustion products were characterized at the inlet and outlet of the air heater in order to determine the air inleakage at the air heater. Control room data supplied information on the performance of the unit. The extensive data sheet included the following parameters (not exhaustive):

- $\quad$ Load $\left(\mathrm{MW}_{\mathrm{e}}\right)$

- $\quad$ Main Steam Pressure, Temperature, and Flow

- $\quad$ Cold and Hot Reheat Pressure and Temperature

- $\quad$ Feedwater Heater \#7 Data Sufficient to Calculate Reheat Steam Flow

- $\quad$ Feeder Speeds (\%)

- $\quad$ Furnace Exit Gas Temperatures (FEGT)

- $\quad$ Economizer and Air Heater Exit Temperatures

- $\quad$ Excess $\mathrm{O}_{2}$ at the economizer exit

- Opacity, $\mathrm{NO}_{\mathrm{x}}$, and $\mathrm{SO}_{2}$ emissions measured by the CEMS

- $\quad$ Fan damper positions 
The test also involved using a video camera positioned on the $9^{\text {th }}$ floor, aimed at the interface between the cyclones and the primary furnace. The camera was used to determine differences in the condition of the flames exiting through the reentrant throat, and to determine the extent of combustion occurring in the primary furnace. The camera provided qualitative information regarding the impact of cofiring on plant operations.

\section{TEST RESULTS}

Test results were divided into issues of operability, efficiency, and emissions. Operability issues included boiler capacity as influenced by feeder speeds, fan damper positions, and economizer temperatures; and stability as measured by statistical evaluations of critical parameters. Efficiency evaluations were made considering fuel quality and operating conditions. Attention was paid to evaluating whether cofiring would increase the required $\mathrm{O}_{2}$. Further, attention was given to the impact of cofiring on unburned carbon in the ash. Emissions were evaluated to determine the impact of cofiring on opacity, $\mathrm{NO}_{\mathrm{x}}$, and $\mathrm{SO}_{2}$. Attention was given to an analysis of mechanisms creating emissions impacts.

\section{Operability Results}

Boiler capacity was of critical concern. Maximum capacity for the unit, during the test, was defined at $425 \mathrm{MW}_{\mathrm{e}}$. During the baseline tests, this posed no problem for feeder speeds, fan damper positions, or economizer exit temperatures. Figure 1 depicts the impact of cofiring on feeder speeds.

Note that the feeder speeds increased with the practice of cofiring. The explanation of this phenomenon is the fact that the wood waste blend contained about $250 \mathrm{Btu} / \mathrm{lb}$ of fuel less than the baseline blend, and that the wood waste blend also had a lower bulk density as influenced by the $18 \mathrm{lb} / \mathrm{ft}^{3}$ density for the biofuel. 


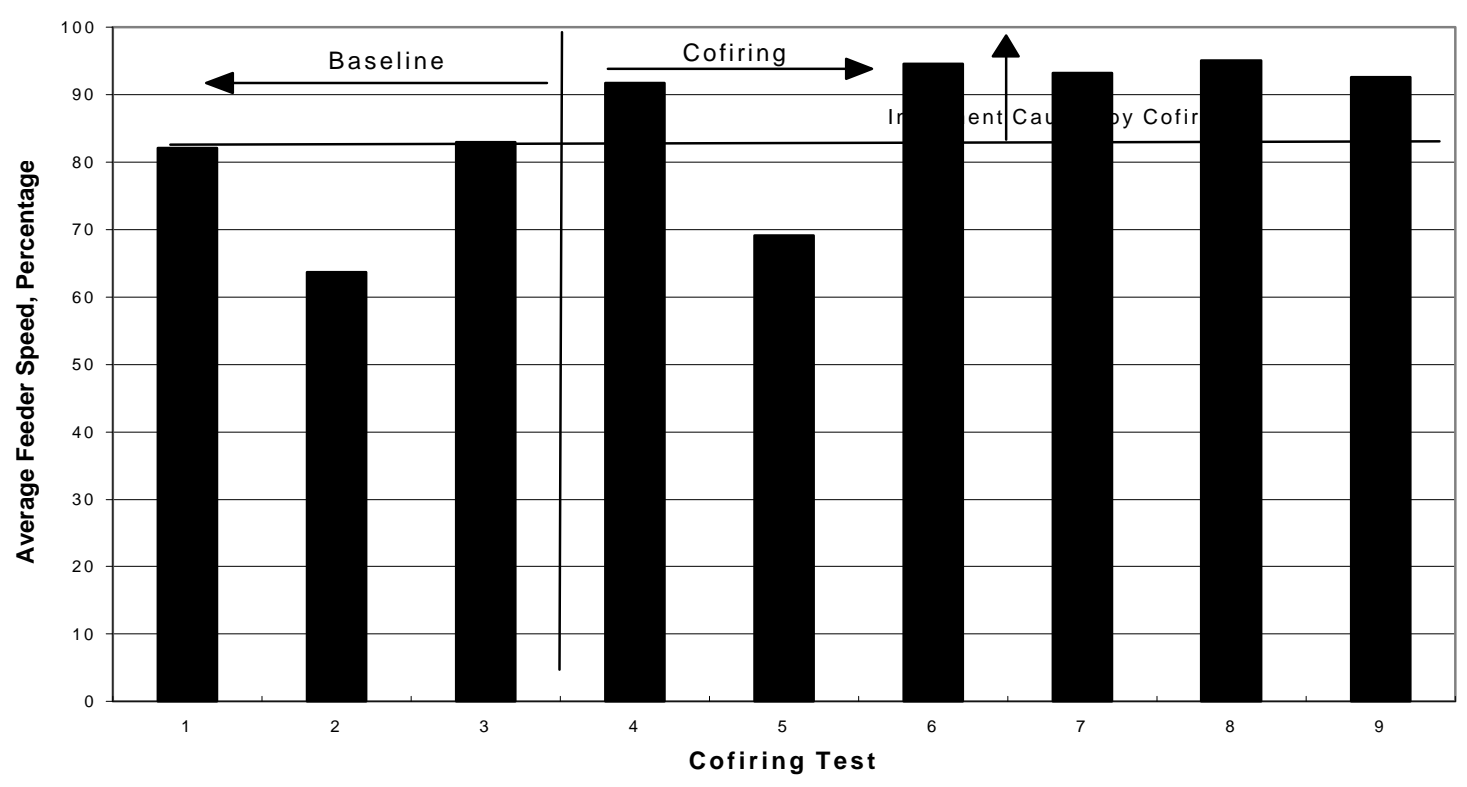

Figure 1. Impact of Cofiring on Feeder Speeds at Michigan City Generating Station

Figure 2 illustrates this feeder impact, and highlights the impact of blend differences.

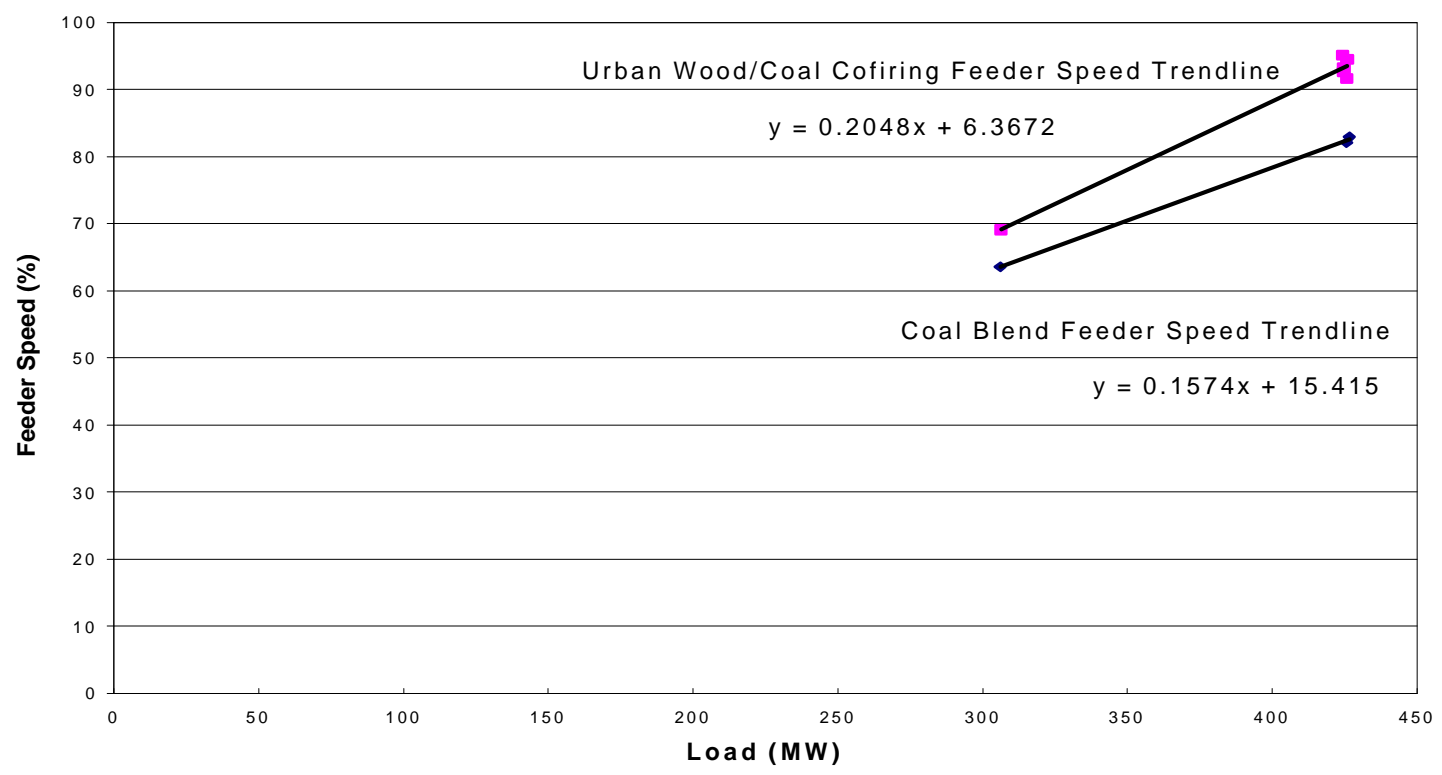

Figure 2. The Influence of Cofiring on the Feeder/Capacity Relationships

Calculations based upon the urban wood/coal cofiring speed trendline indicate that the maximum capacity of the unit when cofiring at 10 percent would be $430 \mathrm{MW}_{\mathrm{e}}$. Above that level the operator would have no upward margin to handle instantaneous events. 
Economizer temperatures were not influenced by cofiring, as is shown in Figure 3. Note that there is neither downward nor upward pressure on this parameter. Note that there is a heavy line at $800^{\circ} \mathrm{F}$, indicating the capacity limitation associated with this parameter.

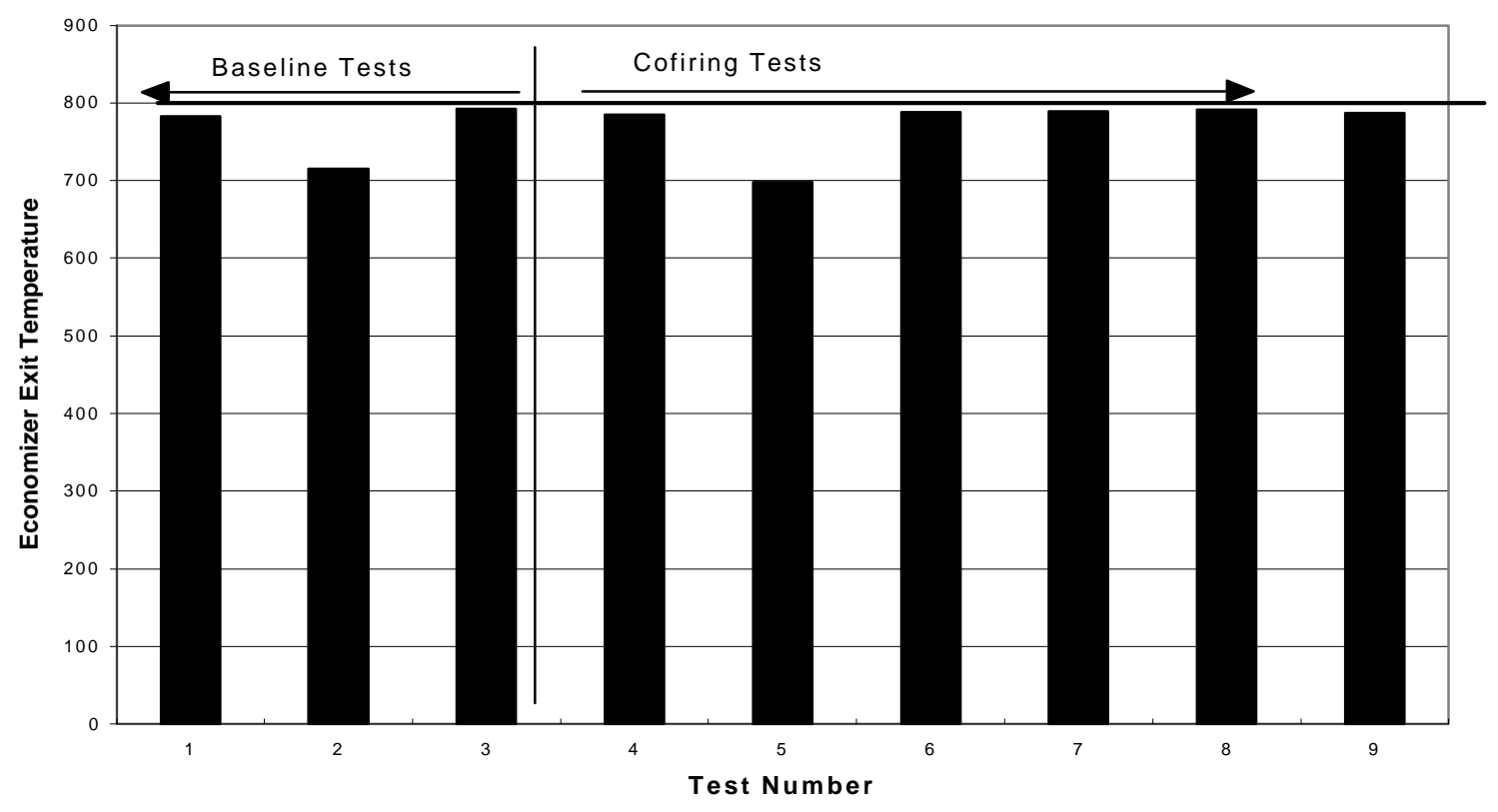

Figure 3. The Influence of Cofiring on Economizer Exit Temperature

Forced Draft and Induced Draft Fan damper positions also were not influenced by cofiring. There was ample excess capacity in the FD fans, indicating that the combustion air requirement was manageable with the existing system. There was ample capacity in the ID fans, indicating that the volume of flue gas formed by burning a lower Btu fuel was within acceptable limits.

Stability was measured by expressing standard deviation as a percentage of the mean, and by expressing the 95 percent confidence interval as a percentage of the mean, for the following parameters: main steam pressure, temperature, and flow; cold and hot reheat pressure and temperature; excess $\mathrm{O}_{2}$, air heater exit temperature, FEGT, feeder speeds, and other key variables. In all cases the boiler exhibited as much stability when cofiring as when being fueled by the coal only blend. The only instability that occurred was when the wood waste blend first entered the boiler; the unit lost $10 \mathrm{MW}_{\mathrm{e}}$ of capacity until the boiler adjusted to the change in fuels. 


\section{Efficiency Impacts of Cofiring}

Efficiency Impacts of Cofiring include not only the basic measured values, but also the parameters governing efficiency: excess $\mathrm{O}_{2}$, air heater exit temperature, unburned carbon in the flyash, fuel moisture, and fuel hydrogen content. Table 2 summarizes the efficiencies measured at the NIPSCO-Michigan City cofiring tests. Note that critical parameters are shown with the efficiencies.

Table 2. Summary of Cofiring Efficiencies at Michigan City Generating Station

\begin{tabular}{|c|c|c|c|c|c|c|c|c|c|}
\hline \multicolumn{10}{|c|}{ Test } \\
\hline & 1 & 2 & 3 & 4 & 5 & 6 & 7 & 8 & 9 \\
\hline Date & $9 / 23$ & $9 / 24$ & $9 / 24$ & $9 / 24$ & $9 / 25$ & $9 / 25$ & $9 / 25$ & $9 / 26$ & $9 / 26$ \\
\hline Start Time & 1400 & 0400 & 0915 & 1700 & 0400 & 0900 & 1400 & 0715 & 1030 \\
\hline End Time & 1800 & 0700 & 1015 & 2000 & 0645 & 1200 & 1645 & 1015 & 1300 \\
\hline Load $\left(\mathrm{MW}_{\mathrm{e}}\right)$ & 425.7 & 306.0 & 426.6 & 425.8 & 306.4 & 425.9 & 424.7 & 424.3 & 424.6 \\
\hline & 3 & 8 & & 5 & 2 & 2 & 5 & 8 & 4 \\
\hline Percent Cofire & 0 & 0 & 0 & 10 & 10 & 10 & 10 & 10 & 10 \\
\hline $\begin{array}{l}\text { Main Steam Flow } \\
(\mathrm{kpph})\end{array}$ & 2914 & 2015 & 2918 & 2878 & 2020 & 2880 & 2881 & 2865 & 2872 \\
\hline $\mathrm{O}_{2}$ Percent & 2.42 & 2.79 & 2.24 & 2.48 & 2.88 & 2.82 & 2.38 & 2.42 & 2.29 \\
\hline AHTR Exit ${ }^{\circ} \mathrm{F}$ & 366 & 318 & 372 & 368 & 316 & 372 & 372 & 372 & 368 \\
\hline $\begin{array}{l}\text { AHTR Inleakage } \\
(\%)\end{array}$ & 5.25 & 8.90 & 7.40 & 7.20 & 5.30 & 7.40 & 6.50 & 8.80 & 9.50 \\
\hline $\begin{array}{l}\text { Unburned } \\
\text { Carbon (\%) }\end{array}$ & 0.75 & 0.57 & 1.18 & 0.65 & 0.62 & 0.76 & 0.69 & 0.93 & NA \\
\hline $\begin{array}{l}\text { Boiler Efficiency } \\
(\%)\end{array}$ & 84.6 & 85.3 & 84.4 & 84.6 & 85.7 & 84.4 & 84.7 & 84.5 & 84.6 \\
\hline
\end{tabular}

What is apparent from Table 2 is the fact that efficiencies were comparable between baseline tests and cofiring tests. However it must be remembered that the baseline tests were performed with Caballo Rojo coal while the cofiring tests were performed with Black Thunder coal. The parameters governing efficiency clearly indicate that cofiring does not cause degradation in the excess $\mathrm{O}_{2}$, the air heater exit temperature, or the unburned carbon in the flyash. Unburned carbon was measured both from samples obtained by traversing the ducts upstream of the air heater, and capturing flyash in a 
thimble; and by obtaining electrostatic precipitator ash hopper samples. A comparison of these values is shown in Table 3 .

Table 3. Unburned Carbon in the Flyash Determined from Thimble and ESP Hopper Samples

\begin{tabular}{|c|c|c|c|}
\hline \multirow[t]{2}{*}{ Test No. } & \multirow[t]{2}{*}{ Percent Cofiring (mass) } & \multicolumn{2}{|c|}{ Unburned Carbon Percent in Flyash } \\
\hline & & Thimble Sample & $\begin{array}{c}\text { Ash Hopper } \\
\text { Sample }\end{array}$ \\
\hline 1 & 0 & 0.75 & 0.64 \\
\hline 2 & 0 & 0.57 & 1.87 \\
\hline 3 & 0 & 1.18 & 0.22 \\
\hline 4 & 10 & 0.62 & 0.54 \\
\hline 5 & 10 & 0.76 & 0.49 \\
\hline 6 & 10 & 0.69 & 0.40 \\
\hline 7 & 10 & 0.93 & 0.16 \\
\hline 8 & 10 & N/A(*) & 0.63 \\
\hline 9 & 10 & $\mathrm{~N} / \mathrm{A}(*)$ & 0.97 \\
\hline
\end{tabular}

Computationally, the cofiring tests were compared to calculations assuming the same operational parameters but also assuming that Black Thunder, rather than Caballo Rojo, were used as the baseline coal. This analysis yielded an efficiency deterioration of about 0.65 percent. This comparison between tests indicates that cofiring can be used to stretch better quality PRB coals, as is shown by Figure 4. 


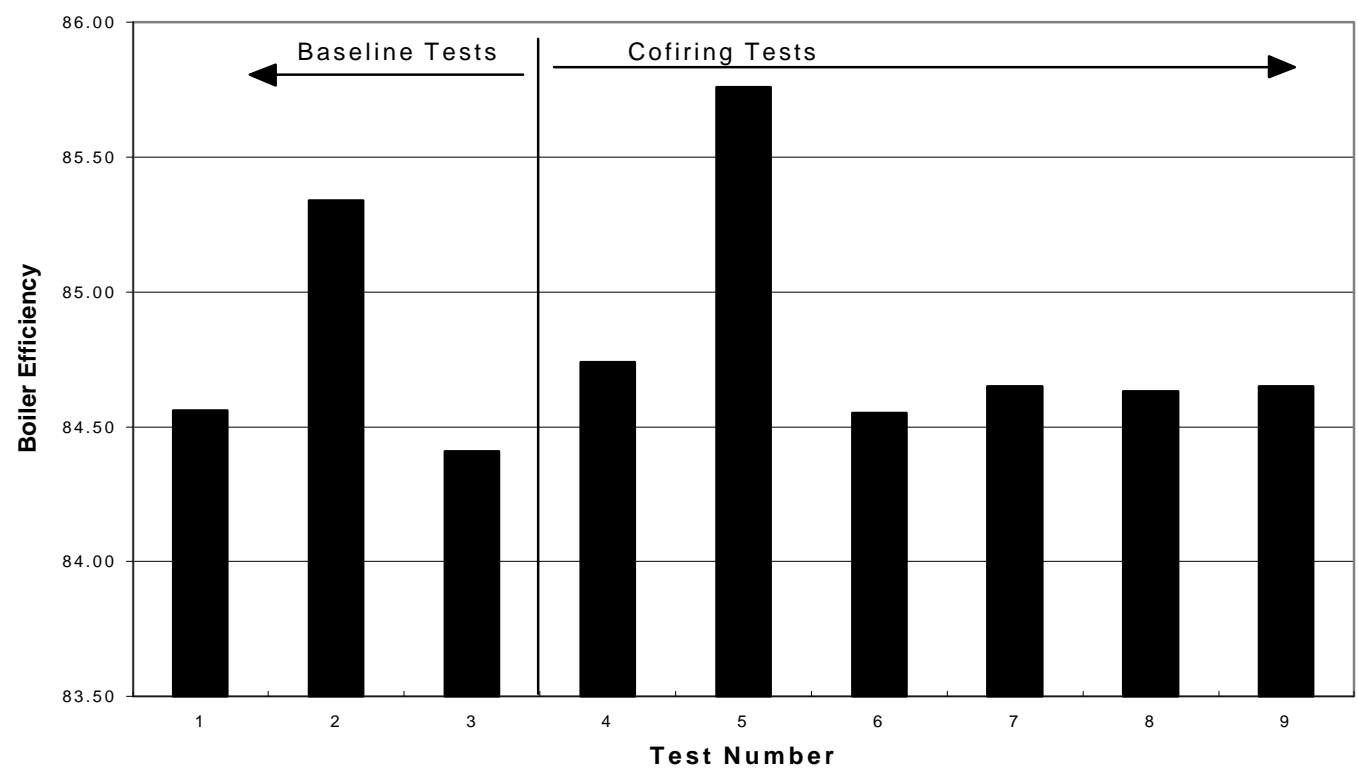

Figure 4. Efficiencies Measured at the Michigan City Cofiring Tests. Note that the Baseline Tests were Conducted with Caballo Rojo Coal while the Cofiring Tests were Conducted with Black Thunder Coal.

\section{Temperature Impacts of Cofiring}

Beyond efficiency, temperature profiles are significant, particularly with regard to flame temperatures, furnace exit gas temperatures, and economizer exit temperatures. These, also, indicate influences of cofiring on unit performance. Figure 5 presents calculated flame temperatures, while Figure 6 presents measured FEGT values. The temperatures shown in Figure 5 were determined using the CET-89 program developed by NASA, using Gibbs Free Energy calculations. Note that there is an increase in flame temperature when cofiring. This results from the volatility of the fuel, and the volatility/flame intensity relationship defined by Shafizadeh (1977) shown below:

$$
I_{f}=(d w / d t) * h
$$

Where $I_{f}$ is flame intensity; dw/dt is the change in weight with respect to time for any given fuel, as measured by thermogravimetric analysis; and $h$ is the heat content of the fuel in Btu/lb or cal/g. Biofuels, with volatile/fixed carbon ratios on the order of 4 to 6 , compared with coals with $\mathrm{V} / \mathrm{FC}$ ratios on the order of 0.5 to 1.0 , dramatically alter the volatility of the fuel mixture to the cyclone at any given time. The cofiring increased the volatility of the fuel blend considerably more than it decreased the overall heat content, 
particularly because of the change in PRB coals used during the test periods. While the flame temperatures increased, the FEGT values decreased as shown in Figure 6. This resulted from more complete combustion in the cyclone barrels and less combustion in the primary furnace.

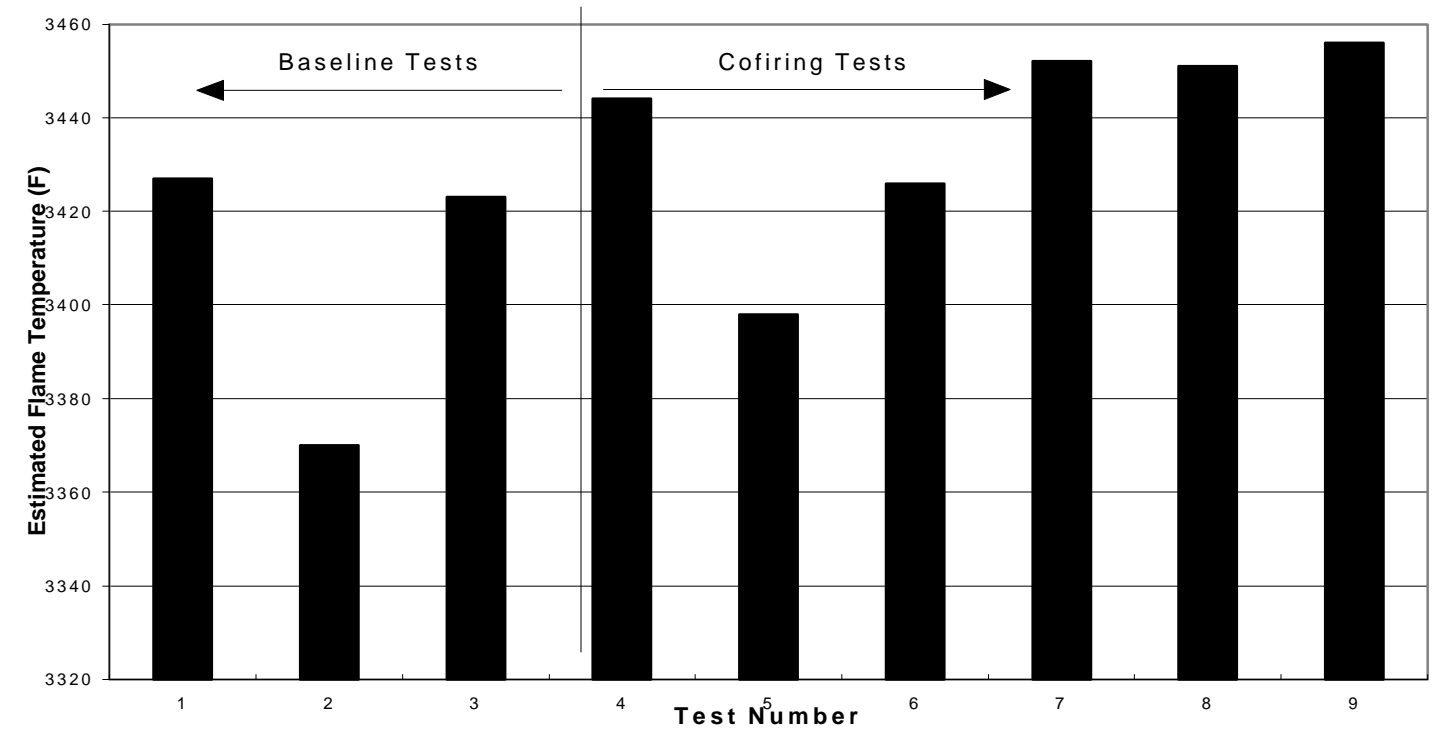

Figure 5. Estimated Flame Temperature as a Function of Cofiring Test

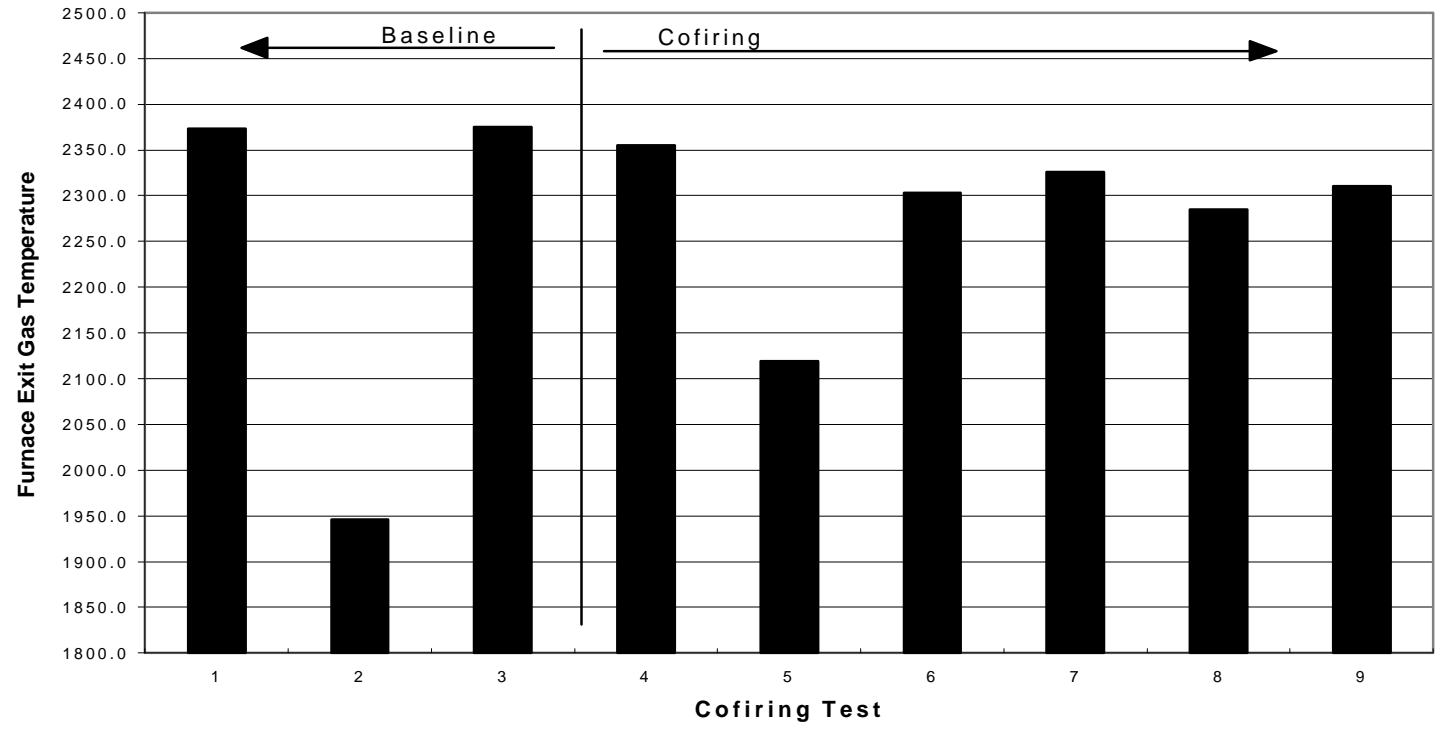

Figure 6. Furnace Exit Gas Temperature as a Function of Cofiring Test

The impact of cofiring on combustion-related temperatures, then, demonstrates that cofiring brings a highly volatile biofuel to the unit, creates early ignition of the fuel in the cyclone barrel, and more complete combustion of the fuel in the cyclone barrel. Operators noticed measurements indicating that more of the ash was removed as slag, through the 
slag taps; less ash was entrained in the gaseous products of combustion as flyash. This phenomenon is consistent with the early ignition of the fuel and more complete combustion in the cyclone barrel.

\section{Emissions Impacts of Cofiring Wood Waste With Coal at Michigan City}

The final topic for consideration is the impact of cofiring on the formation of emissions: opacity, $\mathrm{SO}_{2}$, and $\mathrm{NO}_{\mathrm{x}}$. Table 4 summarizes these results.

Table 4. Airborne Emissions Measured by Michigan City Boiler \#12 CEMS

\begin{tabular}{rccccccccc}
\hline & & $\mathbf{1}$ & Test & & & & \\
Date & $9 / 23$ & $9 / 24$ & $9 / 24$ & $9 / 24$ & $9 / 25$ & $9 / 25$ & $9 / 25$ & $9 / 26$ & $9 / 26$ \\
Start Time & 1400 & 0400 & 0915 & 1700 & 0400 & 0900 & 1400 & 0715 & 1030 \\
End Time & 1800 & 0700 & 1015 & 2000 & 0645 & 1200 & 1645 & 1015 & 1300 \\
\hline $\mathrm{NO}_{\mathrm{x}}\left(\mathrm{lb} / 10^{6} \mathrm{Btu}\right)$ & 1.28 & 1.05 & 1.19 & 1.16 & 1.03 & 1.16 & 1.13 & 1.14 & 1.16 \\
$\mathrm{SO}_{2}\left(\mathrm{lb} / 10^{6} \mathrm{Btu}\right)$ & 0.87 & 0.86 & 0.87 & 0.84 & 0.86 & 0.85 & 0.86 & 0.81 & 0.81 \\
& & & & & & & & & \\
Opacity (\%) & 25.05 & 12.86 & 24.98 & 25.73 & 12.41 & 27.55 & 22.20 & 18.64 & 19.66 \\
\hline
\end{tabular}

Note that the $\mathrm{NO}_{\mathrm{x}}$ and $\mathrm{SO}_{2}$ emissions decreased as a function of cofiring; opacity was more variable, but generally within the range associated with coal-only firing. The mechanism associated with $\mathrm{SO}_{2}$ reduction is substitution of a sulfur-deficient fuel for coal. The mechanisms associated with $\mathrm{NO}_{\mathrm{x}}$ reduction are more complex, however.

Regression analysis applied to the NOx results from the Michigan City tests yields the following equation:

$$
\mathrm{NO}_{\mathrm{x}}=1.764(\mathrm{FN})+0.041\left(\mathrm{O}_{2}\right)+0.0006(\mathrm{FEGT})-2.21
$$

Where $\mathrm{NO}_{\mathrm{x}}$ is measured in $\mathrm{lb} \mathrm{NO}_{\mathrm{x}}\left(\right.$ as $\left.\mathrm{NO}_{2}\right) / 10^{6} \mathrm{Btu}, \mathrm{FN}$ is fuel nitrogen in $\mathrm{lb} / 10^{6} \mathrm{Btu}, \mathrm{O}_{2}$ is the percentage of oxygen in the gaseous combustion products measured at the economizer exit, and FEGT is furnace exit gas temperature, measured in ${ }^{\circ} \mathrm{F}$. The $\mathrm{r}^{2}$ for this equation is 0.979 . The significance of each variable (100 - probability of random occurrence) is as follows: intercept, 99.77 percent; FN, 99.93 percent; $\mathrm{O}_{2}, 71.68$ percent; and FEGT, 99.99 percent. Of these, the FEGT and FN are the dominant terms, while excess $\mathrm{O}_{2}$ may not be a particularly significant variable within the range of conditions 
employed at the Michigan City tests. While the constant for FEGT is apparently low, the values of this parameter are $\geq 2,100^{\circ} \mathrm{F}$ for all but the minimum load cases. Consequently the high values for FEGT reduce the regression term.

Given those regression results, Figure 7 presents the impact of cofiring on $\mathrm{NO}_{\mathrm{x}}$ emissions. Note that it shows a dominant influence of FEGT. Note, further, that the fuel nitrogen probably dominates the difference in the two trend lines.

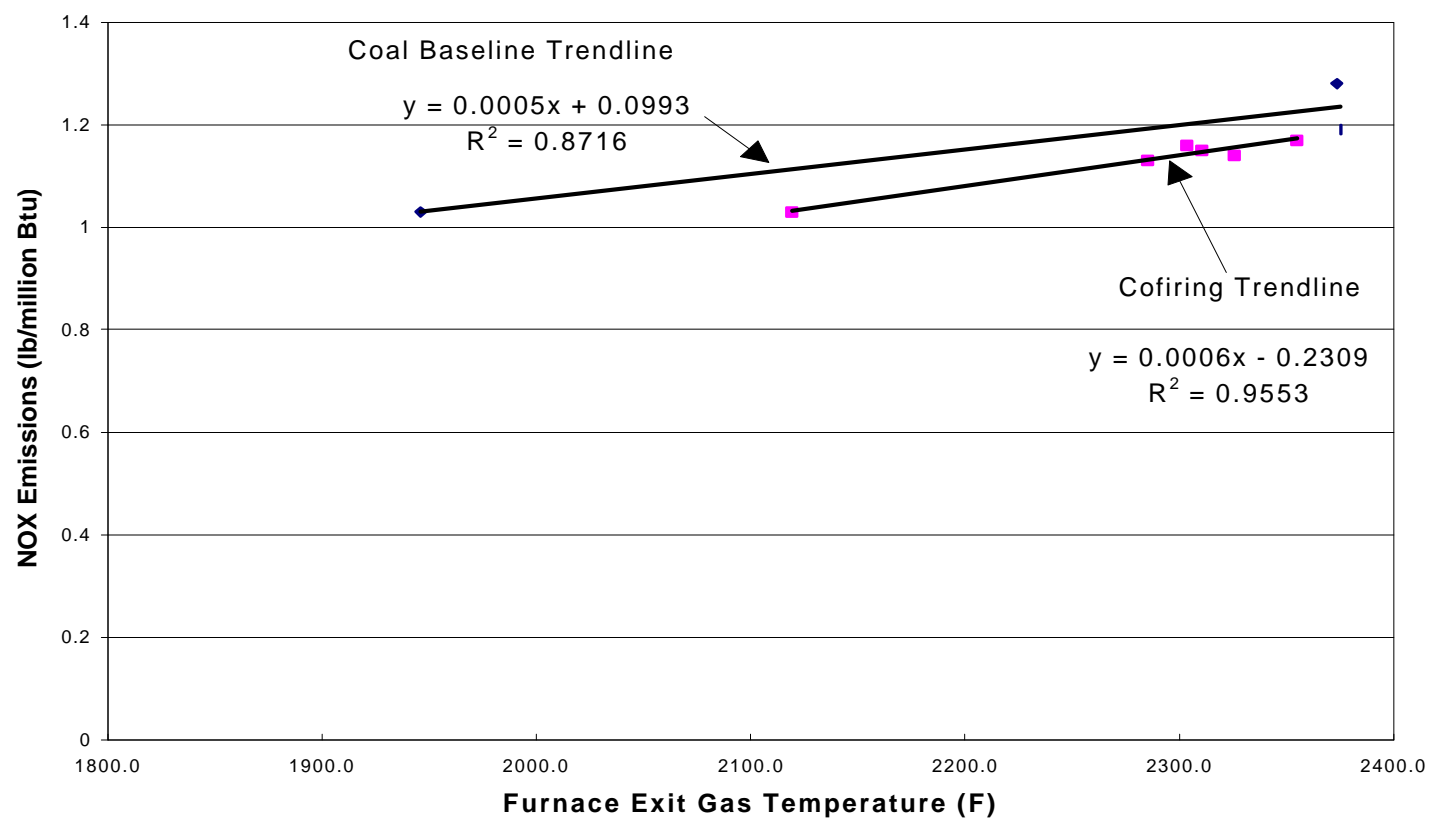

Figure 7. $\mathrm{NO}_{\mathrm{x}}$ Emissions at Michigan City Cofiring Tests as a Function of Furnace Exit Gas Temperature

There is a $\mathrm{NO}_{\mathrm{x}}$ reduction $>9$ percent, created by a fuel substitution of 6 percent (Btu basis). This reduction is the consequence of changing combustion conditions in the cyclones, coupled with changing fuel characteristics. It is largely a result of a much more volatile fuel that is deficient in fuel nitrogen.

The $\mathrm{NO}_{\mathrm{x}}$ data from Michigan City are similar to $\mathrm{NO}_{\mathrm{x}}$ results obtained at the Allen Fossil Plant of TVA (see Tillman, 1996; Tillman et. al., 1996). Further, they document the fact that cofiring can be a $\mathrm{NO}_{\mathrm{x}}$ trim strategy; however it is not a primary tool unless a given boiler is close to meeting regulatory requirements. The Allen Fossil Plant tests, coupled with extensive computer modeling, also documented the impacts of fuel volatility, fuel nitrogen, and a changed combustion profile on $\mathrm{NO}_{\mathrm{x}}$ emissions from cyclone boilers. The 
Michigan City tests demonstrated that such results could be extended to cofiring biofuel with PRB coals.

Fossil $\mathrm{CO}_{2}$ emissions are the final consideration; these are considered to be greenhouse gases. At a load of $425 \mathrm{MW}_{\mathrm{e}}$, the tests demonstrated that hourly savings were on the order of 27 tons $\mathrm{CO}_{2}$. Annual savings are a function of capacity factor, as shown in Figure 8 . Note that cofiring at 10 percent by mass, at a capacity factor of 0.8 , yields a reduction of 170,000 tons $\mathrm{CO}_{2}$ when the unit is rated at $425 \mathrm{MW}_{\mathrm{e}}$. A 5 percent cofiring level would achieve fossil $\mathrm{CO}_{2}$ emissions reductions $>80,000$ tons/year under similar assumptions.

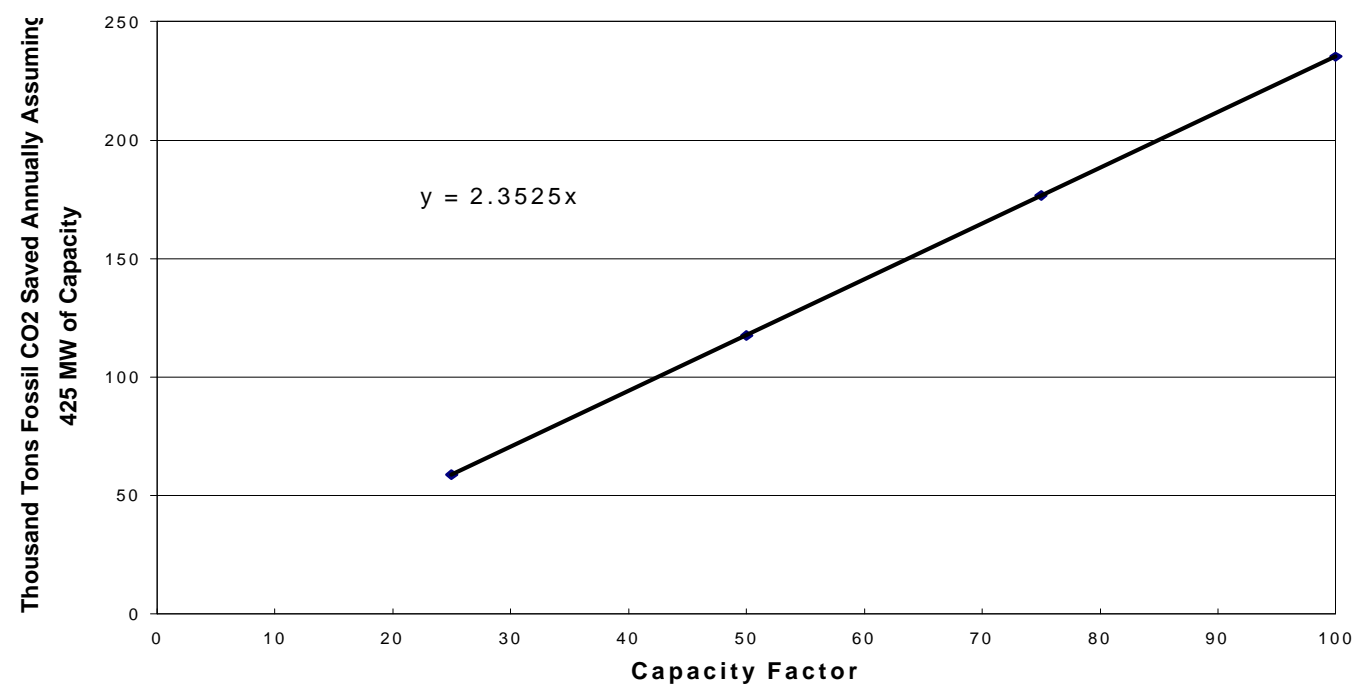

Figure 8. Fossil $\mathrm{CO}_{2}$ Emissions Reductions From Cofiring at Michigan City Conclusions

Cofiring testing at the Michigan City Generating Station was quite successful. While there were feeder speed limitations, these did not reduce capacity at the loads generated by the plant during the test period. Further, those limitations may well be specific to plants firing PRB coals, if the plants were designed for eastern coals such as Illinois Basin bituminous coal. Efficiency degradation provided a cap on the value of the biofuel, but was generally within acceptable levels. The temperature profile documented a changing combustion profile; it also documented no temperature impacts on boiler capacity. Emissions reductions occurred with respect to both $\mathrm{SO}_{2}$ and $\mathrm{NO}_{\mathrm{x}}$. The latter emissions reductions were the result of changing the combustion profile and the fuel to the boiler. The reductions in fossil $\mathrm{CO}_{2}$ when cofiring at this station are quite dramatic. The results of this 
test were sufficiently encouraging that NIPSCO is considering cofiring at other cyclone installations.

\section{References}

Tillman, D.A. 1996. Cofiring Wood Waste in Utility Boilers: Results of Parametric Testing and Engineering Evaluations. Proc. 1996 Joint Power Generation Conference. ASME. Houston, TX. Oct 14-16.

Tillman, D.A. et. al. 1996. Fuel Blending and Switching For $\mathrm{NO}_{\mathrm{x}}$ Control Using Biofuels with Coal in Cyclone Boilers. Proc. Engineering Foundation Conference on Biomass Combustion. Snowbird, UT. Apr 28 - May 3. 